\title{
A new diagnosis and status for Mixobates Thor, 1905 (Acari, Hydrachnidia, Hygrobatidae), with a revision of the palaearctic species
}

\author{
P. Tuzovskij ${ }^{1}$, R. Gerecke ${ }^{2 *}$ \\ ${ }^{1}$ Institute Biology Inland Waters, 152742 Borok, Nekouz district, Yaroslavl province, Russia. \\ 2 Biesingerstr. 11, D-72070 Tübingen, Germany.
}

\begin{abstract}
A revised diagnosis of Mixobates Thor, 1905, is given, including the proposal to rank this taxon as a separate genus. The species so far published from the palaearctic region are revised. Adults of M. caucasicus Tuzovskij, 1990 are described for the first time and the following synonyms are established : M. uncatus Sokolow, $1930=$ M. processifer Thor, 1905 ; M. lundbladi Schwoerbel, $1957=$ M. incurvatus Láska, 1954. The latter species is for the first time recorded from the Mediterranean area. Four new species are described : M. acutidentatus, M. brachypalpus and M. uncatellus from Russia, and M. maghrebinus from Morocco. A dichotomic key for the determination of the palaearctic species is presented.
\end{abstract}

Keywords : Acari, Hygrobatidae, palaearctic, Hygrobates, Mixobates, morphology, systematics, diversity, running waters.

\section{Introduction}

Since its first description by Thor (1905), Mixobates held an ambivalent position in taxonomic bibliography : Introduced as a subgenus, it was elevated to genus rank by Lundblad (1927) - a point of view accepted in several taxonomic revisions and text books (e.g., K.Viets 1956b, K.Viets \& K.O.Viets 1960). However, Habeeb (1957) and Cook (1974) followed Thor's original concept and ranked Mixobates as a subgenus of $\mathrm{Hy}$ grobates Koch, 1837, and this assessment was taken over in the world wide catalogue of K.O.Viets (1987). A total number of eleven species has been described : two from Asia (Sokolow 1930, Tuzovskij 1990), three from Europe (Thor 1905, Láska 1954, Schwoerbel 1957), five from North America (Habeeb 1955, 1957, 1962, Cook 1974), and one from Central America (K.O.Viets 1978). In all parts of their distribution area, Mixobates species «are living in the shadow». They are recorded from patchy localities only, generally

\footnotetext{
*corresponding author : reinhard.gerecke@uni-tuebingen.de
}

found in low numbers of specimens, mostly in mossy riffles of low order streams. No information is available concerning the life cycle of Mixobates species.

The aim of this paper is to revise the diagnosis of this taxon, to discuss the importance of some characters for species discrimination, and to propose a key for the identification of its representants in the palaearctic fauna. Our new data include the first records of the genus from Southern Europe and palaearctic Africa.

\section{Material and methods}

The new material presented here was taken by handnetting the moss carpet on stones in low order streams. Mites were sorted in the field, preserved in Koenike's fluid and dissected in the laboratory for morphological observation and measurements. For slide mounting, Hoyer's fluid was used. The types of the new species will be preserved at the Senckenberg Museum Frankfurt (material from Morocco) and in the collections of the Institute of the Academy of Science at Borok (material from Russia).

Our setae terminology (Fig. 1,2) follows Tuzovskij (1987) : Fch - setae of the cheliceral segment, Fp -setae of the palpus segment, $\mathrm{Vi}$ - verticales internae, Ve 


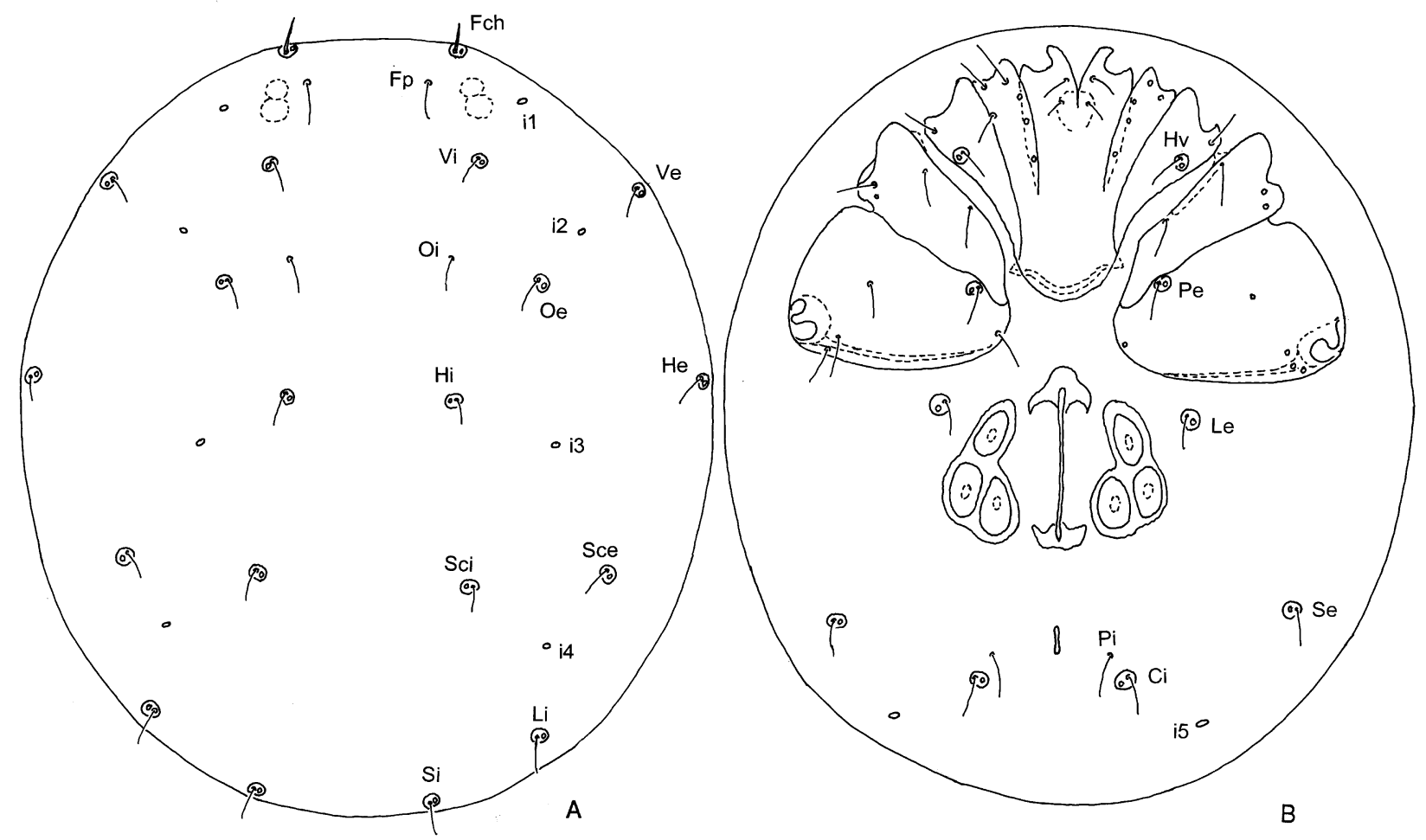

Fig. 1. Setae terminology in Hygrobates-like water mites (following Tuzovskij, 1987, based on the example of Hygrobates nigromaculatus, female). A dorsal view, B ventral view.

- verticales externae, Oi - occipitales internae, Oe occipitales externae, $\mathrm{Hi}$ - humerales internae, $\mathrm{He}$ - humerales externae, Hv - humerales ventralia, Sci - scapulares internae, Sce - scapulares externae, Li - lumbales internae, Le - lumbales externae, $\mathrm{Si}$ - sacrales internae, $\mathrm{Se}$ - sacrales externae, $\mathrm{Ci}$ - caudales internae, $\mathrm{Pi}$ - praeanales internae, $\mathrm{Pe}$ - praeanales externae. A comparison of this terminology and other systems more currently used in Western Euroipe and the United States is given by Gerecke \& Tuzovskij (2001).

The following further abbreviations are used : CS = collection Schwoerbel ; $\mathrm{Cx}-2=$ second coxae $; \mathrm{H}=$ height ; L = length ; I-L-5 = first leg, fifth segment ; MMB = Moravian Museum Brno ; P-2 = palpus, segment 2 ; SMF = Senckenberg Museum Frankfurt ; SMNH $=$ Swedish Museum of Natural History Stockholm ; $\mathrm{W}=$ width.

\section{Diagnosis of Mixobates Thor, 1905}

Both sexes : Membranous integument usually with a very fine striation, occasionally striae bundled to wider strips as they are found e.g. in the subgenus Pseudole- bertia (Lebertia, Lebertiidae) ; no sclerotized muscle attachments dorsally and ventrocaudally ; excretory pore smooth ; integument of sclerotized body parts (coxae, genital plates, appendages) rather fine and transparent ; genital field with three pairs of acetabula ; anterior coxal plates fused medially and with the posterior margin of the gnathosoma ; posterior coxal plates separated from anterior ones by a stripe of membranous integument, or (rarely) all coxae fused to a unique plate due to secondary sclerotization ; in mature specimens both Cx-3 (laterally) and Cx-4 (laterally and caudally) with extended border of secondary sclerotization, and caudal margin of $\mathrm{Cx}-4$ with a protruding muscle attachment apodeme ; a large glandulare (Pe) perforating the central surface of $\mathrm{Cx}-4$; all leg claws with a ventral clawlet and a narrow claw blade ; no swimming hairs present ; I-L-5 in the centre of the ventral margin with a pair of short setae, at the distal margin anteriorly a fine, whip-like seta, and ventrodistally two strong, apically rounded setae nearly equal in length ; I-L-6 with numerous long ventral setae, the distal ones curved around the distoventral edge of the segment, with their tips directed to the claw base ; che- 


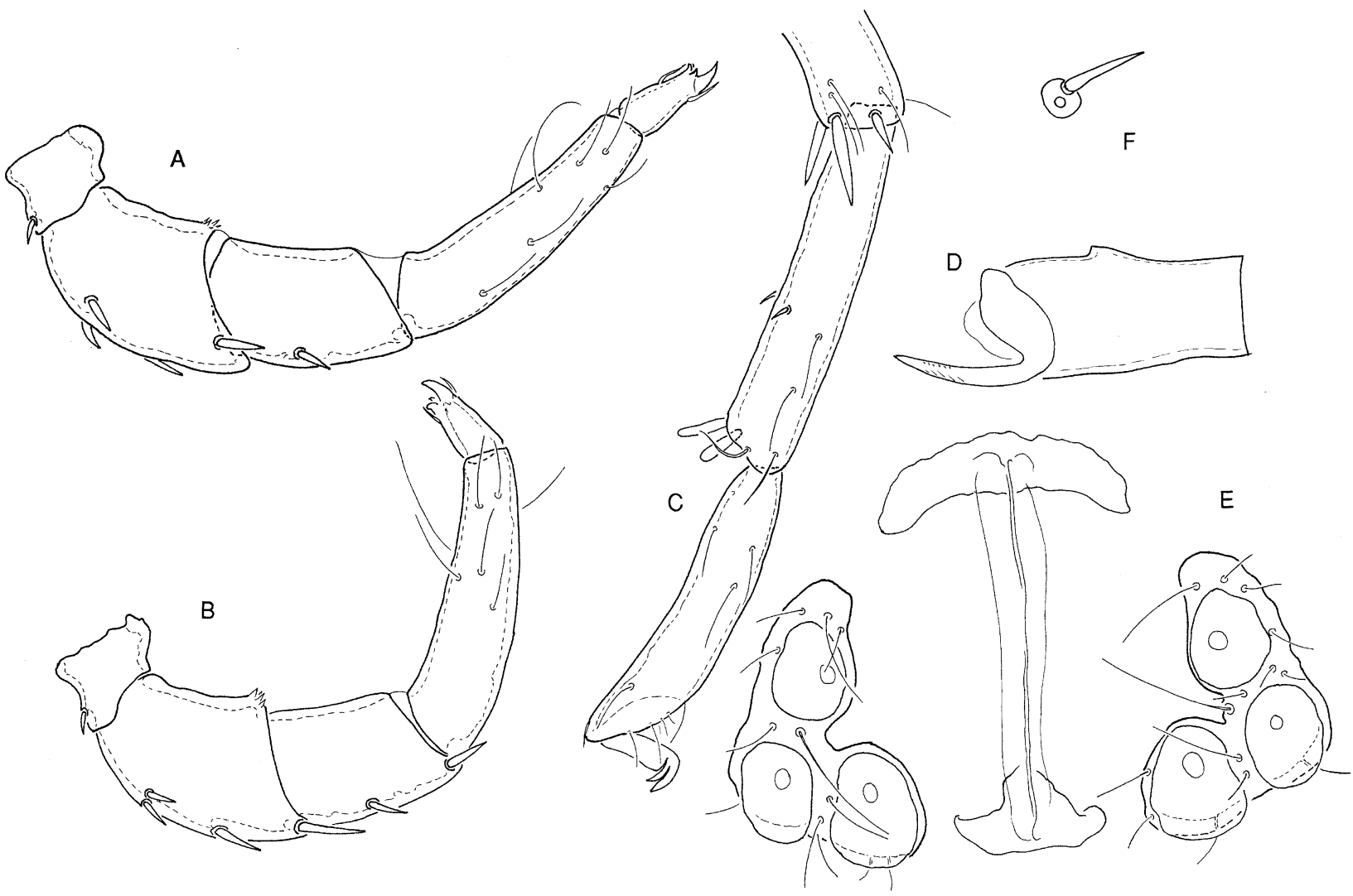

Fig. 2. Mixobates processifer, female. A-E specimen from Sweden (SMNH 961), F specimen from Russia. A palpus medially, B palpus laterally ; C I-L-5/6 ; D Chelicera, claw and anterior part of basal segment ; E genital field ; F setae Fch.

licera with straight claw and a small pointed projection on the dorsal surface of the basal segment ; palpus with P-2 denticulated ventrodistally, here bearing a more or less protruding (sometimes nearly absent) projection, P-3 ventrally smooth or with a low number of fine denticles, P-4 slender, without projections or denticulation, bearing two ventral hairs arranged close to each other slightly distally from the centre of the segment, and several additional fine hairs laterally and dorsally ; P-5 longish, with one very long distal claw and two additional hook-like claws directed ventrally.

Male : gonopore completely surrounded by genital sclerite.

Female : sclerotization of genital plates fewly extended, with medial margin deeply indented between the acetabula, sometimes anterior acetabula completely separated.

In his proposal to rank Mixobates as a subgenus of Hygrobates, Cook (1974) paid much attention to the position of the glandular opening on the surface of $\mathrm{Cx}$ -
4, demonstrating that the position of this organ is rather variable in genera of Hygrobates-like mites. However, for the taxonomic ranking of these taxa, more attention should be paid to the modification and arrangement of setae on the first leg (Gerecke 2000, in press). There is much reason to consider the 'hand' of Atractides-like mites (consisting of a I-L-5 with a whip-like anterodistal, and a pair of variously modified ventrodistal setae, and a I-L-6 with numerous ventral setae, the distalmost of which bent towards the claw base), as a particular sense (not grasping!) organ that has originated once in the evolution of Hygrobatidae. On the base of this hypothesis, Atractides-like genera are a monophyletic group that has undergone strong adaptive radiation, and Mixobates should be considered a member of this clade rather than a subgenus of Hygrobates. Mixobates is similar to Mesobates Thor, 1901 both in the modified shape and setation of I-L (performed in a very different manner in these two taxa, but synapomorphic in confront to Hygrobates), and in the broad fusion of the gnathosoma to the ante- 
rior coxal group (found similarly in Hygrobates, plesiomorphic with regard to Atractides). This scenario gives satisfactory reason to maintain Mixobates as a separate genus. Additional research on morphology and life cycles of tropical Atractides-like genera is needed for a better understanding of the phylogenetical systematics of Hygrobatidae.

\section{Presentation of the palaearctic species}

\section{Mixobates processifer (Thor, 1905)}

Hygrobates (Mixobates) processifer Thor, 1905

Mixobates uncatus (Sokolow, 1930), nov. syn.

Material examined : SMNH 961 (532), Hygrobates processifer S.Thor Q Dalarna : Leksands socken, Yxan en bit nedanför Yxen. 17.7.1918. Leg. O. Lundblad ; two further Qㅇ, same locality : SMNH 5986 ; from vial material prep. Gerecke 2000. Russia, Ussuri catchment, river Edinka in the Primorye Territory reserve, Vschivkowa, $10^{\prime}, 1$ 우 ; republic Komi, river Kojym (affluent of river Pechora), Tsember, 06.08.1987, $20^{7} 0^{7}$; Northeastern Kolsky peninsula, river Iokanga, 14.08.1987, 2 우.

M. uncatus (Zoological Institute of the Academy of Science St. Petersburg), holotype $0^{7}$ prep. Nr. 674, paratype $\sigma^{7}$ prep. Nr. 673 , o prep. Nr. 679.

Female : Idiosoma L 620-670, W 560-570 $\mu \mathrm{m}$, integument smooth, locally with a very fine striation ; dorsoglandularia small, diameter about $15 \mu \mathrm{m}$, with fine hairs, no sclerotized muscle attachments ; coxae (as given in Fig. $3 \mathrm{C}$ for the male) and legs only weakly sclerotized, with a very fine, irregularly arranged porosity, proximal margins of all coxal plates irregular due to borders of secondary sclerotization ; $\mathrm{CX}-1+2$ incl. gnathosoma medial L 198-204, W 247-270 $\mu \mathrm{m}$, with equally rounded posteromedial margin ; Cx-3+4 L 234-256 $\mu \mathrm{m}$, glandulare Pe placed at a distance of 15-25 $\mu \mathrm{m}$ from the suture line $\mathrm{Cx}-3 / 4$; Cx-4 with medial margin equally convex, posterior margin nearly straight, at the mediocaudal edge with a slightly protruding muscle attachment apodeme; legs with slender segments bearing relatively short setae, without swimming hairs ; first leg as depicted in Fig. $2 \mathrm{C}$ : I-L-5 dL 150-154, maximum H 27-31 $\mu \mathrm{m}, \mathrm{L} / \mathrm{H}$ 4.90-5.56, with a pair of ventral setae placed slightly distally from the centre of the segment, a fine whip-shaped seta anteriorly at the distal margin, and a pair of club-shaped ventrodistal setae (L-17-20 $\mu \mathrm{m})$; I-L-6 similar in shape as compared with distal segments of II-IV-L (in one specimen asymmetrically thickened on one side due to individual misshapening), L 130-134, maximum H 25-
$27 \mu \mathrm{m}, \mathrm{L} / \mathrm{H}$ 4.96-5.56, L ratio I-L-5/6 1.13-1.15, with ventral and dorsal margins equally diverging distally, several long ventral setae and a tuft of curved setae inserted ventrally and posteriorly near the anterior edge and directed towards the claw base ; claws of all legs with a lobiform ventral clawlet and a narrow claw blade ; genital field (Fig. 2 E) L/W 175/215 $\mu \mathrm{m}$, praegential sclerite crescent-shaped, W 100-112 $\mu \mathrm{m}$, made up by a relatively narrow central part and lateral rami of weaker secondary sclerotization ; postgenital sclerite with pointed lateral edges, W 58-63 $\mu \mathrm{m}$, W ratio praegenitale/postgenitale 1.6-1.9; genital plates L 100-114, W 58-67 (measured on the level of the posterior acetabula $65-85) \mu \mathrm{m}$, formed by a narrow sclerite frame surrounding the three oval acetabula and bearing 11-15 setae, medial margin deeply indented on the level of the second acetabula ; maximum diameter of acetabula : $1.42-44,2.35-44,3.41-45 \mu \mathrm{m}$; up to 17 eggs per female 150-160 $\mu \mathrm{m}$ in diameter, covered by an envelope $12 \mu \mathrm{m}$ in thickness, with a radial internal structure ; excretory pore caudally from the $\mathrm{Pi} / \mathrm{Ci}$; Pi (represented by a seta only, with reduced glandular pore) on a separate platelet, not fused with $\mathrm{Ci}$; gnathosoma broadly fused to the anteromedial margin of $\mathrm{Cx}-$ 1 ; chelicerae not suitable for measurements (a damaged basal segment and claw given in Fig. 2D) ; palpus (Figs $2 \mathrm{~A}, \mathrm{~B}, \mathrm{n}=2$ ) total L 359-373 $\mu \mathrm{m}$, segment measurements (L/H) P-1 29-34/38 ; P-2 92-99/56-63 ; P-3 70-72/44-47 ; P-4 125-128/29-34 ; P-5 40-43/16-18 ; $\mathrm{L} / \mathrm{H}$ ratio/relative L [\%] P-1 0.76-0.89/8-9 ; P-2 1.571.64/26-27 ; P-3 1.53-1.59/19 ; P-4 3.76-4.31/34-35 ; P-5 2.22-2.69/11-12 ; ventral margin of P-2 slightly concave, distally forming an acute angle covered by a group of 5-7 larger and 1-2 small denticles ; ventral margin of P-3 smooth, straight or slightly convexely protruding ; P-4 with a slight concavity at the base of the ventral margin, and dorsal and ventral margins equally converging distally, a pair of long ventral hairs inserted medially and laterally in the distal half of the segment ; P-5 longish, with four claws, three of which hook-like and curved, and one strongly protruding distally.

Male (first description, based on specimens from Ussuri, Russia) : General shape of coxae, legs and mouthparts similar to female, but minor in dimensions. Idiosoma L 600-620, Genital field (fig. 3D) roundishtriangular in shape, L 105, W $120 \mu \mathrm{m}$; acetabula covering a large part of the area of the plates, in triangular position (with equal distances between Ac-1/2 and -3) ; 11-13 genital hairs on each side ; gonopore with maximum width near its anterior edge, posteriorly equally narrowed. 


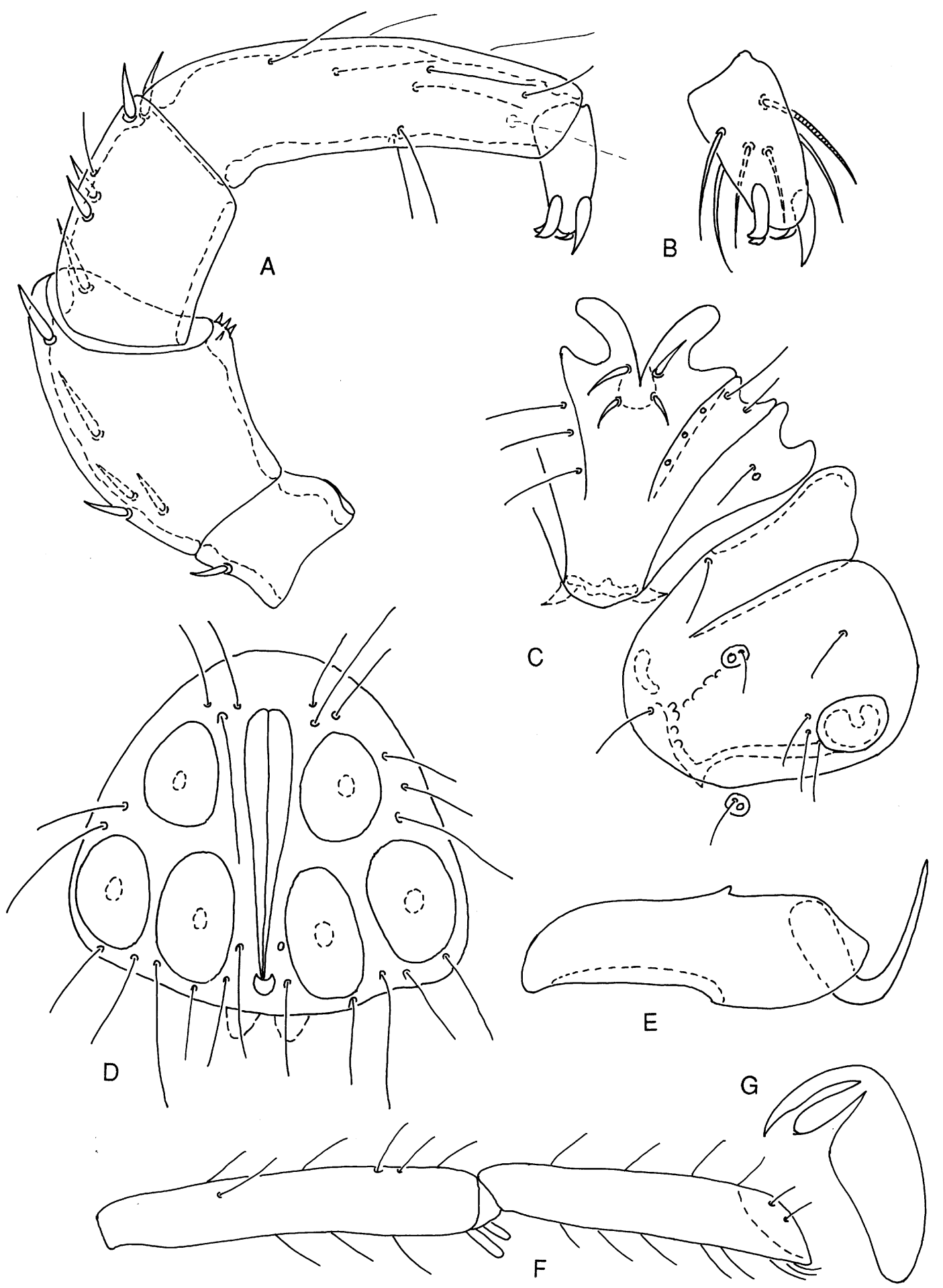

Fig. 3. Mixobates processifer, male specimen from Russia. A palpus laterally ; B P-5 ; C coxal field, partial view ; D genital field ; E chelicera ; F I-L-5/6 ; G I-L, claw. 
Palpus as given in Fig. 3 A ; P-1-5 (L) 30, 80, 60, $115,30 \mu \mathrm{m} ; \mathrm{P}-2$ with concave ventral margin, bearing a group of 3-4 dents at the distal edge ; ventral margin of P-3 smooth ; P-4 gradually narrowed from the base to the tip, with a pair of fine hairs near the centre of the segment. P-5 (Fig. 3 B) elongate, dorsodistal seta strong, distinctly projecting beyond the distal end of the segment, ventrodistal setae similar to each other in shape and dimensions. Chelicera (Fig. 3 E) basal segment L 145, claw L $65 \mu \mathrm{m}$. Leg measurements (L of segments 1-6) I-L 45, 65, 80, 115, 125, 115, II-L 50, 75, 85, 130, 140, 130, III-L 55, 80, 100, 150, 170, 150, IV-L 120, 105, 135, 185, 210, $170 \mu \mathrm{m}$; ventrodistal setae on I-Leg-5 (Fig. 3 F) slightly differing in length ; claws with a well developed claw blade, internal clawlet slightly shortened and distally rounded (fig. 3G).

Variability : Two male specimens from the Komi area (Fig. 4) differ from the description given above in slightly minor dimensions (idiosoma L 570-610 $\mu \mathrm{m}$ ), the anterior margin of $\mathrm{Cx}-3$ fused to posterior margin of Cx-2. Furthermore, they have a larger genital field (L 135-145, W 165-180 $\mu \mathrm{m}$ and 6-7 denticles on P-3. The measurement range of palps and legs is as follows : palp segments 1-5 L 25, 80-85, 65-75, 105-110, 30-35 $\mu \mathrm{m}$; leg segments 1-6 L : I-L 40-50, 75-80, 80-85, 135-140, 145-150, 130-140 ; II-L 45-50, 75-80, 90-100, 145-150, 150-165, 150-155 ; III-L 55-65, 75-80, 105-115, 160-165, 155-180, 160-165; IV-L 105-110, 95-105, 135-140, 185-190, 200-205, 185-190 $\mu \mathrm{m}$. The females from this collecting site agree with the description given above ; the measurement range of palps and legs is as follows : leg segments 1-6 L : I-L 45-50, 80-90, 90-100, 135-150, 145150, 130-140 ; II-L 50-55, 80-85, 95-100, 150-155, 155-170, 140-145 ; III-L 60-65, 80-85, 105-110, 165-185, 165-180, 145-165 ; IV-L 85-90, 90-110,

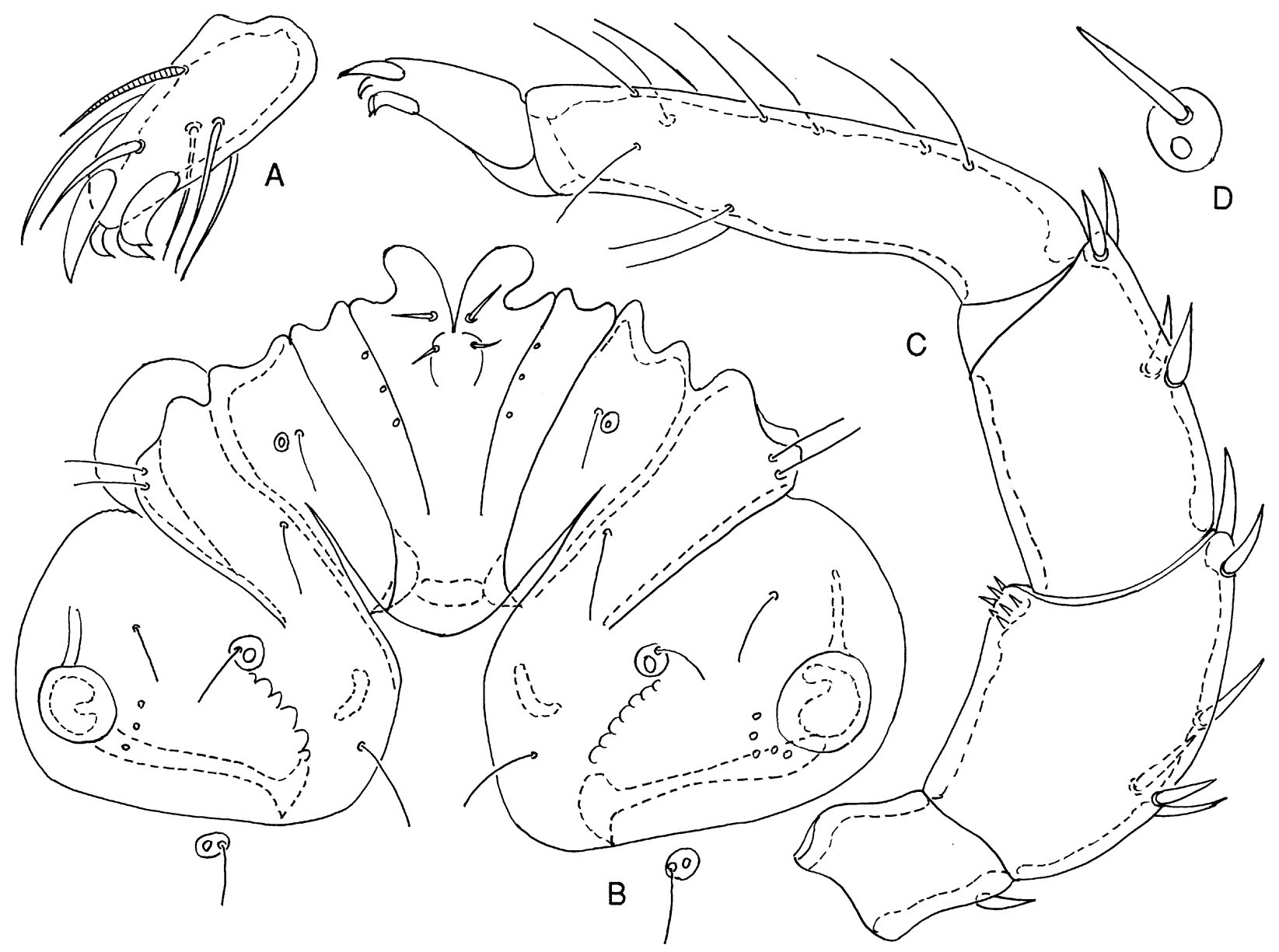

Fig. 4. Mixobates processifer, male from Komi area (N Russia). A P-5 ; B Coxal field ; C palpus ; D seta Fch. 
145-155, 195-200, 200-225, 180-190 um ; palp segments 1-5 L 25-30, 100-105, 75-80, 135, 35 um. We interprete these differences as a consequence of individual variability. A tendency of fusion between anterior and posterior coxal plates at higher age is found also in several species of the Hygrobatid genus Atractides (Gerecke in press).

From most points of view, our morphological details agree with the original description of the female, but remarkable differences regard the genital field and the P-2. Following Thor's text, $M$. processifer lacks genital plates, but in his figure, a sclerotized frame surrounding the acetabula is clearly recognized. Obviously a weak development of these structures is a characteristic feature of all Mixobates species. Furthermore, Thor describes and figures the presence of 12-14 denticles at the ventrodistal tip of P-2. Since the first description, such a high number has never been found again in any species of the genus. As we could clarify with the control of one unprepared specimen, the fact that Thor obviously figured the palpus in an oblique position from a medioventral viewpoint gives no explanation for this difference. However, accumulation of granulated material in this area (as we could observe in one of our specimens as well) could have induced Thor to calculate an excessive number of 'denticles'. For the time being, there is no reason to question Lundblads determination for the only available Scandinavian specimens. As the holotype of this species has gone lost with the destruction of the collection Thor, we base our diagnosis of $M$. processifer on the description given above, with the possible exception that the number of ventral denticles on P-2 might be amount up to 14 , possibly due to intraspecific variability.

When Sokolow described M. uncatus from Siberia, he placed it into the genus Hygrobates without paying any attention to the existence of $H$. (Mixobates) processifer, and the eventual similarity between these two taxa. As a consequence, the diagnosis proposed by the author refers exclusively to characters suitable for separating Mixobates from Hygrobates. One minor difference to our description of $M$. processifer regards the presence of some small tubercles on the ventral surface of P-3, but they were found asymmetrically on one palpus only. With uncertainty, similar structures were observed also by Thor in his first description ('perhaps 2-3 unsignificant peglets may be seen'), and also in other species of the genus they are found more or less developed or completely absent in specimens belonging to a single population. In a later paper, Sokolow (1934) described also the male (thus giving the first description of the male sex of Mixobates) and mentioned the close relation of $M$. uncatus and M. processifer, but still without indicating diagnostic differences. In his key, Sokolow (1940) differenciated M. uncatus from $M$. processifer (in parentheses) as follows : P-2 and P-3 ventrally slightly concave (slightly convex) ; praegenital sclerites strongly enlarged (with weakly extending lateral rami). From our redescription results that both characters are not suitable for separating the two species - in the contrary, $M$. processifer displays perfectly the character states assigned by Sokolow to M. uncatus. Probably, his description for M. processifer specimens from N Russia (Archangelsk), is based on juveniles which in general have smaller praegenital sclerites and weakly sclerotized, easily deformed palps. Thus, $M$. uncatus should be considered a synonym of $M$. processifer, and the male described by Sokolow under this name represents the male of the typus generis.

M. processifer is distributed in the $\mathrm{N}$ part of the palaearctic region : Scandinavia (Thor 1905, Lundblad 1927, 1962, Böttger \& Ullrich 1974), Northern and Eastern Russia (Sokolow 1940 and our new data) and southwards until Czechia (Láska 1966). The figures published by Angelier et al. (1963) suggest that their record from Central France refers to a different species characterized by the well denticulated ventral margin of $\mathrm{P}-3$ as it is found in $M$. caucasicus. From our present knowledge, we find a border line in Eastern Central Europe between the distribution areas of the Northern $M$. processifer and the Southern M. incurvatus (see below).

\section{Mixobates incurvatus (Láska, 1954)}

Hygrobates (Mixobates) incurvatus Láska, 1954

Mixobates lundbladi Schwoerbel, 1957, nov. syn.

Material examined : Lectotype $\%$, here designated, MMB '147. Mixobates incurvatus Láska 1954 1 o Syntypus' 'Invent. E. 3849/Ent Mor. muzeum, Brno' '373-1 Bicla Orava v Námestova 17.7.1951 leg. Láska' ; paralectotype $ᄋ$ (mounted together with two 우 of H. properus) '145 Hygrobates properus Láska 19542 우 H.incurvatus 1 우 'Syntypus' 'Invent.E. 3848 4074-75/Ent. Mor.muzeum, Brno' '369-1 Studený potok v Podbietu-Orava 16.7.1951 leg. Láska'. Italy 425, Calabria, Serra San Bruno (CZ), Torrente S.Brunello, XC 19 70, 1100 m, 28.07.1986 Gerecke $10^{7}, 2$ 우 ; Greece 6, Epiros, Thesprotia, affluent of river Acheron from Frosíni, QR $8215,150 \mathrm{~m}$, 19.05.1991 Gerecke 1 ㅇ.

Specimens designated as «M. lundbladi» (CS) : Holotype 우 'Mixobates lundbladi $\$$ TYPUS 850' 'Woll- 
bach ob. Wollbach/Schwarzwald Aug. 1956' ; paratype Q, like holotype, but 'COTYPE 851' ; 우 'Schwarzwald, Steina 9/89, Nebenbach Ütiswald' ; O 'Schwarzwald', no collecting site identified, prep. Gerecke 1999.

Female : (measurements for the lectotype, paralectotype in parentheses, organs and structures not particularly mentioned are shaped as in $M$. processifer) : Idiosoma L/W 560/450 (620/450) $\mu \mathrm{m}$, integument striation well visible, with about 7 striae/10 $\mu \mathrm{m}$; coxae (Fig. $5 \mathrm{E}$ ) in the lectotype not measurable, in the paralectotype Cx-1+2 median L (incl. gnathosoma) 204, W 237, Cx-3+4 L 247, W $180 \mu \mathrm{m}$; all coxae proximally surrounded by borders of secondary sclerotization, glandular pore Pe distanced from suture line $\mathrm{Cx}-3 / 4$ by 40-50 $\mu \mathrm{m}$; measurements of I-L (Fig. $5 \mathrm{~A}$ ) can be taken from the paralectotype only : I-L-5 L 143,
H $29 \mu \mathrm{m}$ (L/H 4.93), club-shaped setae L 16 ; I-L-6 L 134, H $25 \mu \mathrm{m}$ (L/H 5.36), L ratio I-L-5/6 1.07 ; genital field L/W 180/140 $\mu \mathrm{m}$, praegenitale W 78 (81), postgenitale W 58 (61), W ratio prae-/postgenitale 1.34 (1.33) ; genital plate L 92 (103), W 56 (58), W on the level of the posterior acetabula $63(63) \mu \mathrm{m}$, medial margin with deep indentation on the level of the second acetabula ; maximum diameter of acetabula 1-3 : 28 (40), 32 (42), 32 (35) $\mu \mathrm{m}$; chelicerae (Fig. 5 D) in the types not measurable ; palpus (Fig. $5 \mathrm{~B}, \mathrm{C}$ ) total L 342 (344) $\mu \mathrm{m}$, segment measurements (L/H) P-1 29/29 (23/32), P-2 78/56 (80/54), P-3 67/49 (68/40), P-4 125/29 (130/27), P-5 43/16 (43/14); L/H ratio/relative L [\%] : P-1 1.00/8 (1.39/7) ; P-2 1.39/23 (1.48/23) ; P3 1.60/20 (1.70/20) ; P-4 $4.31 / 37$ (4.81/38) ; P-5 $2.69 / 13$ (3.07/13) ; L ratio $\mathrm{P}-2 / 40.62$; ventral margin of $\mathrm{P}-2$ concave, distally protruding in a pointed tip,

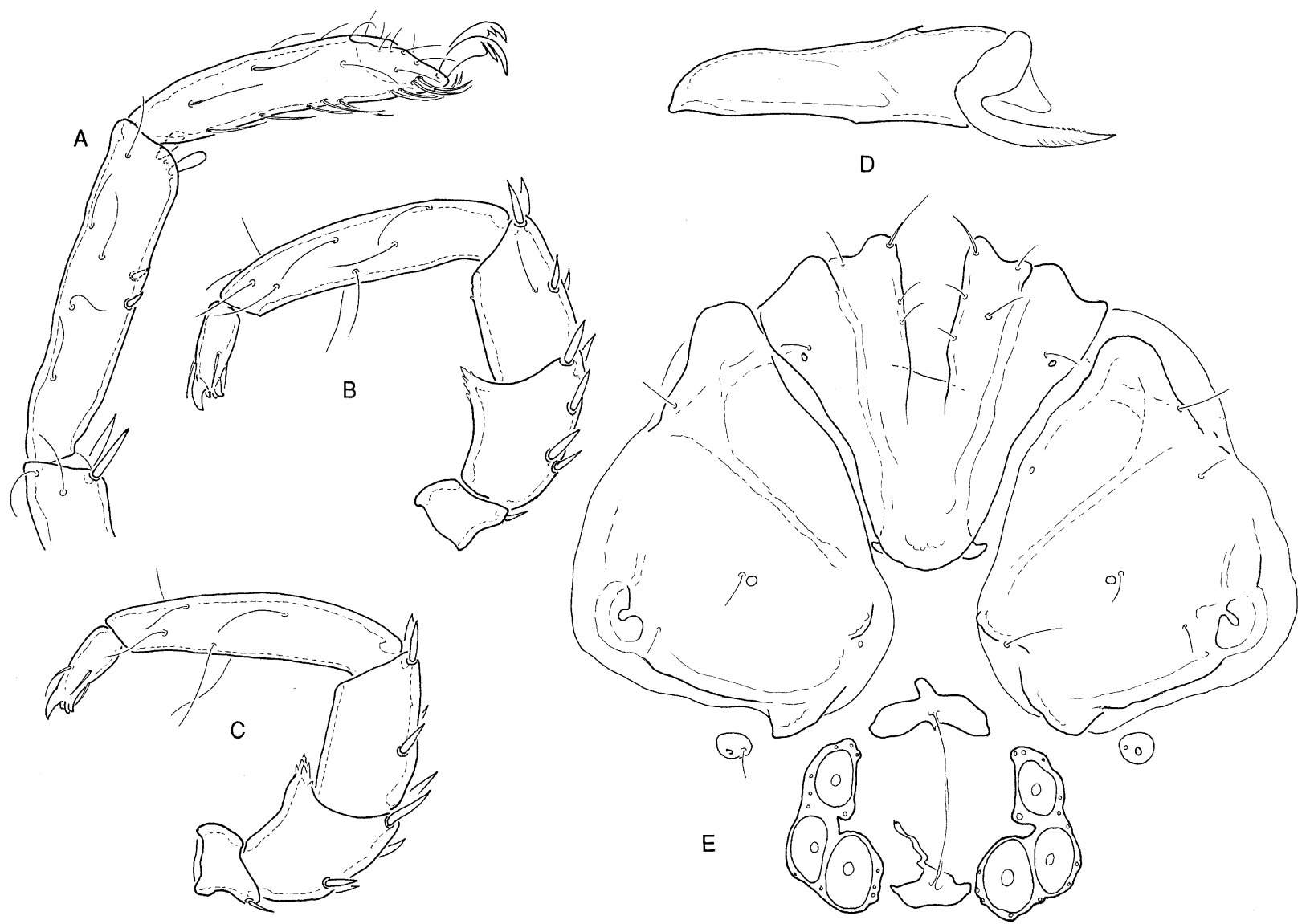

Fig. 5. Mixobates incurvatus, female. A-C Germany, black forest ex coll. Schwoerbel ; D, E holotype. A I-L-5/6 ; B palpus lateral view ; C palpus medial view ; D chelicera ; E coxal and genital field. 
bearing 2-5 larger dents and one small denticle ; P-3 with nearly straight or slightly convex ventral margin, in the distal third occasionally with slight rugosity, or bearing a few small denticles ; P-4 slender, ventral margin with a concave basal sector, maximum H distanced about $25 \mu \mathrm{m}$ from the base of the segment, insertion of the pair of ventral hairs dividing the ventral margin in two sectors proximal/distal $2: 1$.

Variability : The female specimens from Italy differ in slightly minor measurements (e.g. idiosoma L 500515 , palp total L $322-337 \mu \mathrm{m}$ ), a more robust palpus (L/H P-3 1.34-1.42, P-4 3.83-3.84), a higher L ratio P2/P-4 (0.70-0.71) and more slender genital plates (W on the level of Ac-3 45-49 $\mu \mathrm{m})$. In the single female from Greece no noteworthy differences are found to Central European specimens.

Male (first description, based on a specimen from Calabria, Italy) : Idiosoma L 450, W $400 \mu \mathrm{m}$; Coxal field similar to female, Cx-1+2 median L 175, Cx-3+4 L 225, W $180 \mu \mathrm{m}$; genital plate (Fig. 6 D) triangular in shape, with rounded anterior margin, gonopore large, with maximum width slightly anterior from the centre, acetabula small, arranged in a triangle. I-L-5/6 rather slender : I-L-5 L/H 138/29 (4.8), with short club setae (L $10 \mu \mathrm{m}$ ), I-L-6 L/H 128/29 (4.4). Chelicera basal segment L 108, claw L 58 ; palpus (Figs 6 A-C) slightly more robust than in females; total L 297, segment measurements (L/H) P-1 23/25, P-2 73/52, P-3 55/41, P-4 109/31, P-5 37/13; L/H ratio/relative L [\%] : P-1 0.92/8 ; P-2 1.40/25 ; P-3 1.34/19 ; P-4 3.52/37 ; P-5 $2.85 / 12$; L ratio $\mathrm{P}-2 / 40.67$; ventral margin $\mathrm{P}-3$ smooth, dorsodistal seta of P-5 (Fig. 6 B) little curved, strong.

In the original description, Láska renounced to a discussion of the diagnostic features of $M$. incurvatus. Obviously, he was not aware that he had to deal with a representative of Mixobates and regarded the presence of the glandular opening Pe as a sufficient criterion for separating this taxon from the remaining species of Hygrobates. Only in a later publication (Laska 1959a), he placed his species in Mixobates. M. incurvatus differs from $M$. processifer in the position of the glandularia Pe more distanced from the suture $\mathrm{Cx}-3 / 4$, a slightly more slender and relatively longer I-L-6, less enlarged praegenital sclerites, the P-2 with more protruding ventrodistal protrusion (and therefore a lower $\mathrm{L} / \mathrm{H}$ ratio), and more slender $\mathrm{P}-3$ and $\mathrm{P}-4$, with maximum $\mathrm{H}$ of P-4 distally from the base of the segment.

When Schwoerbel published M. lundbladi, he was not yet informed about the description of $M$. incurvatus. Indeed, all diagnostic features that he elaborated in comparison with $M$. processifer and $M$. uncatus, apply to $M$. incurvatus, and the holotype of M. lundbladi and all further specimens from Schwarzwald agree with our description of that species. They differ from the holotype of $M$. incurvatus in larger acetabula, but are in agreement with the measurements of the paratype : maximum diameter 1. 37-47, 2. 42-47, 3. 38-47 $\mu \mathrm{m}$. Some important measurements are (holotype, further specimens in parentheses) : idiosoma L 650 (560-670) $\mu \mathrm{m}$, distance glandulare Cx-4 - suture Cx-3/4 40-47 $\mu \mathrm{m}$; praegenitale $\mathrm{W} 76$ (81-85) $\mu \mathrm{m}, \mathrm{W}$ ratio prae/postgenitale 1.55 (1.27-1.57), palpus total L 363 (340361) $\mu \mathrm{m}$; proportions of palpus and I-L in the type specimens not measurable due to squeezing, in the remaining specimens P-3 H 36-40 $\mu \mathrm{m}, \mathrm{L} / \mathrm{H}$ 1.72-1.92, P$4 \mathrm{H} 25-28 \mu \mathrm{m}, \mathrm{L} / \mathrm{H}$ 4.59-5.20. Among the specimens from Germany, there is some variability in the length of the ventrodistal projection of P-2, in one specimen even a strong difference between the left and right palpus, but in no case it is short and blunt as in M. processifer. A slight difference between the German specimens and the type series from Slovakia is found only in the more stout distal segments of the first leg $(\mathrm{L} / \mathrm{H} \mathrm{I}-$ L-5 4.11-4.90, I-L-6 4.96-5.11), but regarding the L ratio I-L-5/6, the types of $M$. incurvatus lie within the variability range of the specimens from Schwarzwald (1.07-1.12).

Obviously, $M$. incurvatus is a species rather widely distributed in Central and Southern Europe. Our records from Greece and Italy mean the first detection of species of the genus in Mediterranean Europe.

\section{Mixobates caucasicus Tuzovskij, 1990}

Material examined : Russia, Sewersk region, Krasnodar, River Ubin close to the settlement Ubinskaja, June 1976, Tuzovskij, 3 రారా, 2 우, 1 deutonymph.

Male : Idiosoma L 560-790 $\mu \mathrm{m}$; Setae Fch two times longer than their insertion sclerite (Fig. $7 \mathrm{E}$ ). CX$1+2$ posteriorly narrowed and with a strongly curved posteriomedial margin (Fig. 7 C) ; suture line between $\mathrm{Cx}-3 / 4$ almost complete, glandularia $\mathrm{Pe}$ in the anterior part of the surface of $\mathrm{Cx}-4$, posterior margin of $\mathrm{Cx}-4$ with distinctly projecting muscle apodemes. Genital field (Fig. 7 D) L 115-130, W 120-140 $\mu \mathrm{m}$, shaped as an equal-sided triangle, with a nearly straight caudal margin medially interrupted by a pair of incisions near the postgenital sclerite ; acetabula large, Ac-2 and -3 arranged at the same level; gonopore short, about $50 \%$ plate length, with maximum diameter near its anterior edge ; 15-17 genital hairs on each side.

Legs, segments 1-6, L : I-L 40-50, 75-80,75-80, 115-120,120-125,110-120, II-L 45-55, 65-75, 80-90, 120-130, 140-145, 120-130, III-L 50-55, 65-80, 


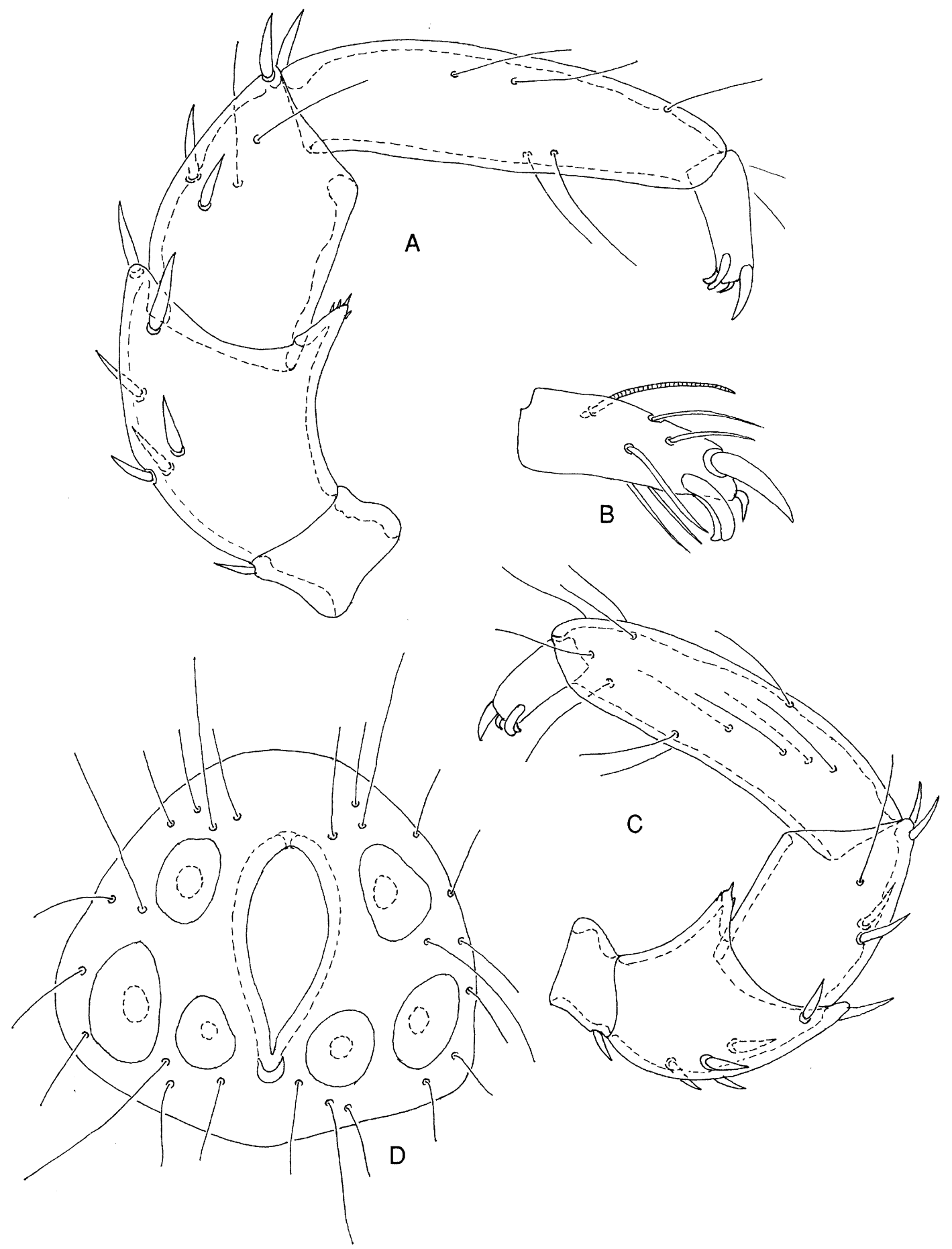

Fig. 6. Mixobates incurvatus, male from Calabria, Italy. A palpus, lateral view ; B P-5 ; C palpus, medial view ; D genital field. 

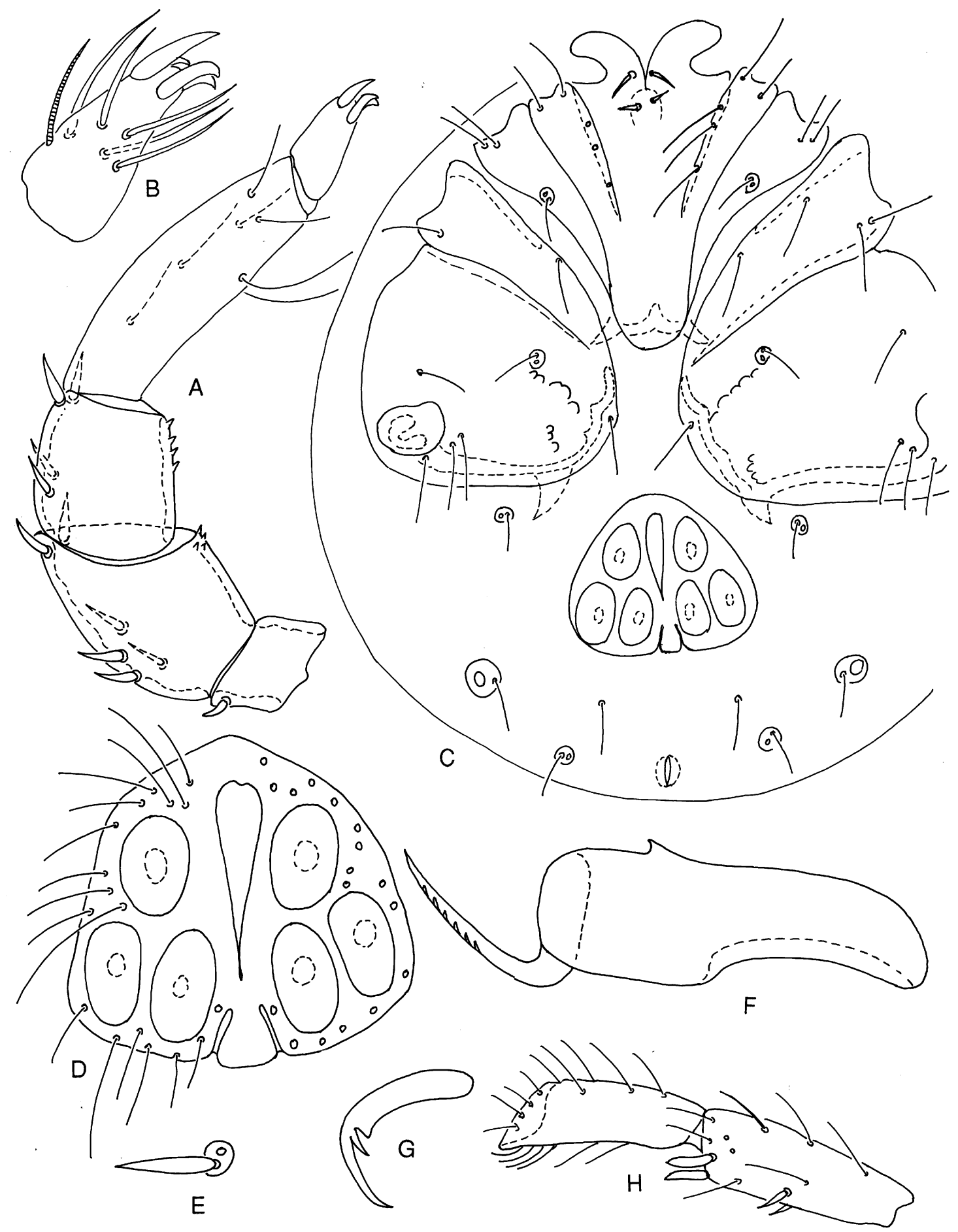

Fig. 7. Mixobates caucasicus, male from the locus typicus. A palpus, lateral view ; B P-5 ; C ventral idiosoma ; D genital field ; E seta Fch ; F chelicera ; G I-L claw ; H I-L-5/6. 
100-115, 140-155, 160-170, 145-155, IV-L 125-130, 90-100, 125-135, 180-190, 205-215, 165-170. Setae S$1 / 2$ on I-L-5 rather strong (L $25 \mu \mathrm{m}$ ) and slightly pointed (Fig. 7 H). Claw of I-L-6 (Fig. 7 G) with little developed claw blade and a rather short internal clawlet (about 1/3 L dorsal claw).

Chelicera (Fig. 7 F) basal segment L 130-145, claw L 60-75 $\mu \mathrm{m}$, hook-like, with a thin and rather straight distal part ; palpus (Figs 7 A, B) segments L P-1 25-30, P-2 75-80, P-3 55-65, P-4 105-115, P-5 30-40 um ; P-2 with 2-4 denticles arranged at the ventrodistal edge of the segment, but without projection in this area ; P-3 with 3-5 dents in the distal part of its ventral margin ; P-5 (Fig. 7 B) basally thick, gradually narrowed to the tip, dorsodistal seta straight, ventrodistal setae curved, equal in size.

Female : Idiosoma L 490-690 ; similar to male in the shape of coxae (Fig. 8 B). Leg segments L (1-6) : I-L 40-50, 65-80, 75-80, 115-120,120-125, 115-120, II-L 45-50, 65-75, 80-85, 125-130, 135-140, 125-130, III-L $45-5,75-80,95-100,145-155,165-170,150-155$, IV-L 120-130, 85-90, 130-140, 170-180, 195-205, 165-170. Genital plate (Figs 8 C, D) L-shaped L 80-90, W 50-55 $\mu \mathrm{m}$, acetabula in triangular position, large, covering a large part of the plate surface, on each plate 9-12 hairs ; genital sclerites well developed ; chelicera basal segment L 155-165, claw L 70-75 $\mu \mathrm{m}$; palp (Fig. 8 A) segments L : P-1 25-35, P-2 75-80, P-3 60-65, P-4 105-115, P-5 35-40 ; P-2 and P-3 with straight ventral margins, bearing 3-4 and 3-5 ventrodistal denticles respectively ; $\mathrm{P}-4$ gradually narrowed from the base to the tip.

This is the first description of adults of M. caucasicus which was so far known from the deutonymph only. The species is similar to $M$. processifer (and differs from $M$. incurvatus) in the absence of a distinct ventrodistal projection on the P-2 and the rather robust $\mathrm{P}-4$, and, in males, in the rather large acetabula. However, it differs from that species in (1) the mediocaudal margin of Cx-1+2 strongly rounded ; (2) I-L-5 with rather long setae S-1/2 ; (3) leg claws with weakly developed claw blade and ventral clawlet ; (4) male gonopore shortened ; (5) presence of ventral denticles on P-3.

\section{Mixobates acutidentatus Tuzovskij sp.n.}

Material examined : Holotype male (prep. Nr. 1826), Russia, Sewersk region, Krasnodar, River Ubin 3 kom upstream settlement Ubinskaja, Tuzovskij, 05.06.1976.
Male (female unknown) : Idiosoma L $505 \mu \mathrm{m}$; Seta Fch (Fig. 9 A) thick and not longer than the diameter of its insertion sclerite. $\mathrm{CX}-1+2$ posteriorly narrowed and with a strongly curved posteriomedial margin (Fig. 9 B) ; suture line between $\mathrm{Cx}-3 / 4$ almost complete, glandularia $\mathrm{Pe}$ in the centre of $\mathrm{Cx}-4$, posterior margin of Cx-4 with distinctly projecting, large-based muscle apodemes. Leg segments 1-6 L : I-L 45, 65, 80, 115, 125, 115, II-L 50, 75, 85, 130, 140, 130, III-L 55, 80, 100, 170, 150, IV-L 120, 105, 135, 185, 210, 170 um ; I-L-5 (Fig. 9 G) with S-1 slightly longer than S-2 ; claw with moderately advanced claw blade, and internal clawlet about half as long as external claw (Fig. 9 H) ; genital field (Fig. 9 F) L 105, W 120 um, roundish-triangular in shape, gonopore rather short, about $50 \%$ plate L ; acetabula small in dimensions, separated by extended interspaces of genital plate sclerite ; 7-9 genital hairs on each side. Chelicera (Fig. 9 E) basal segment L 145, claw L $65 \mu \mathrm{m}$, crescent-shaped ; Palp (Figs 9 C, D) short, L of segments P-1-5 : 30, 80, $60,115,30 \mu \mathrm{m} ; \mathrm{P}-2$ ventrodistally without projection, bearing 2-3 small sharp dents ; ventral margin of P-3 straight and without dents ; P-4 slightly thickened in the centre of the segment ; P-5 (Fig. 9 D) L $1.8 \mathrm{x}$ its height, dorsodistal claw long and nearly straight, ventrodistal claws hooked and distinctly shorter, equal in shape.

M. acutidentatus is similar to $M$. processifer in the shape of the palp (P-2 without ventrodistal projection, P-3 without denticulation), but differs from that species in the leg claws with shorter internal clawlet and less developed claw blade, I-L-5 with longer setae S$1 / 2$, and the smaller acetabula and shorter gonopore in the male genital field. Common features of M. acutidentatus and $M$. caucasicus, a species cooccurring in the same catchment, are found in the suture line $\mathrm{Cx}-3 / 4$ reaching the medial margin of the plate, and the I-L-5 with rather large setae S-1/2. However, the latter species differs in longer setae Fch, the glandulare Pe not in the centre of $\mathrm{Cx}-4$, but approached to the suture line $\mathrm{Cx}-3 / 4$, leg claws with less developed claw blade and internal clawlet, and distincly major Ac in the male genital field.

\section{Mixobates brachypalpis Tuzovskij sp.n.}

Material examined : Holotype male, prep. 1671, Russia, Sewersk region, Krasnodar, River Ubin close to the settlement Ubinskaja, 21.05.1976 ; paratypes : same collecting site, May 1976, Tuzovskij, $50^{7} 0^{\prime \prime}$, 7 O̊, 1 deutonymph.

Male : Idiosoma L 470 - $530 \mu \mathrm{m}$; Setae Fch (Fig. 10 A) thickened, only slightly longer than the diameter of 

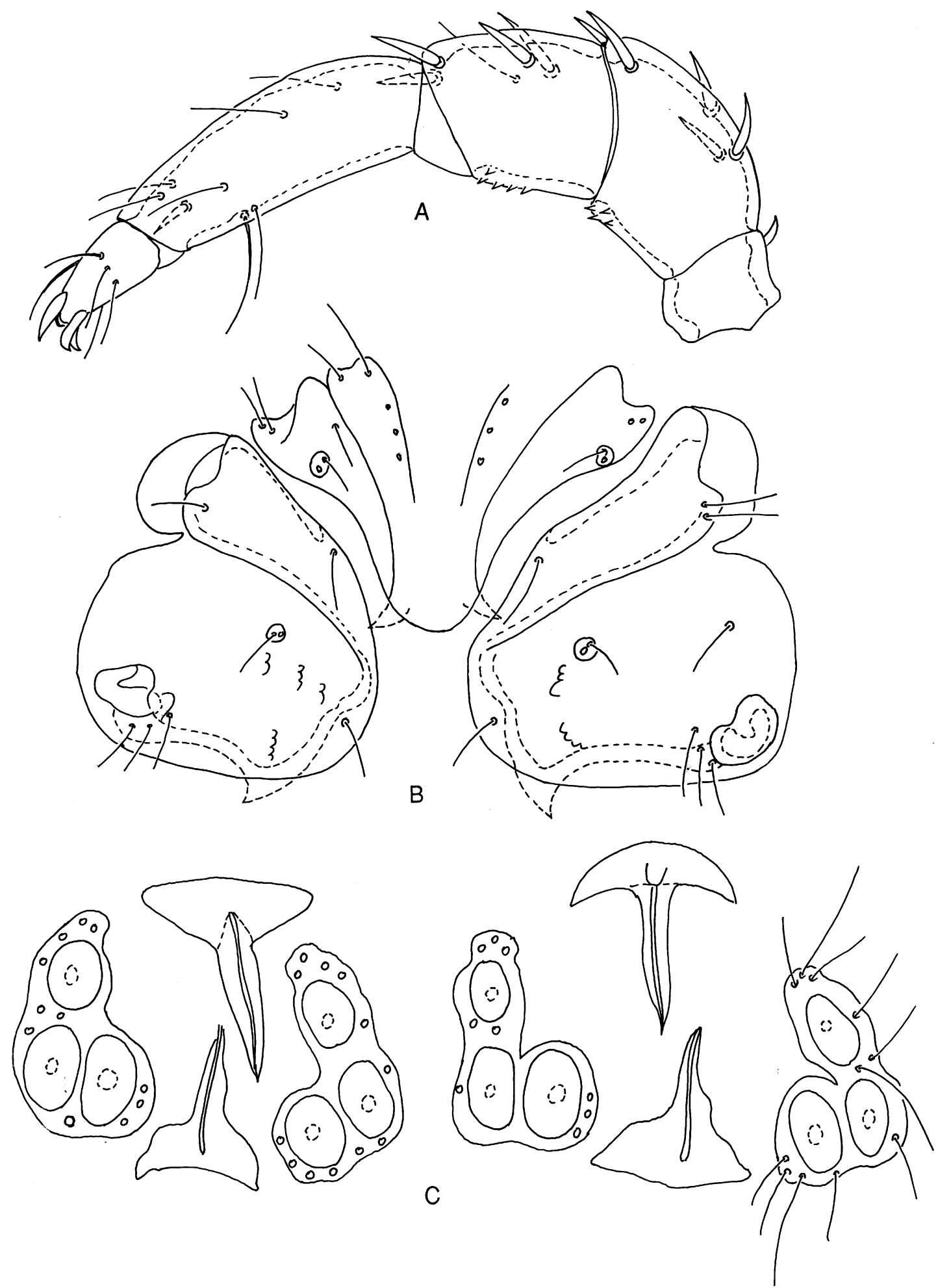

Fig. 8. Mixobates caucasicus, females from the locus typicus. A palpus ; B coxal field ; C genital fields of two specimens (the division of the gonopore is an artifact). 

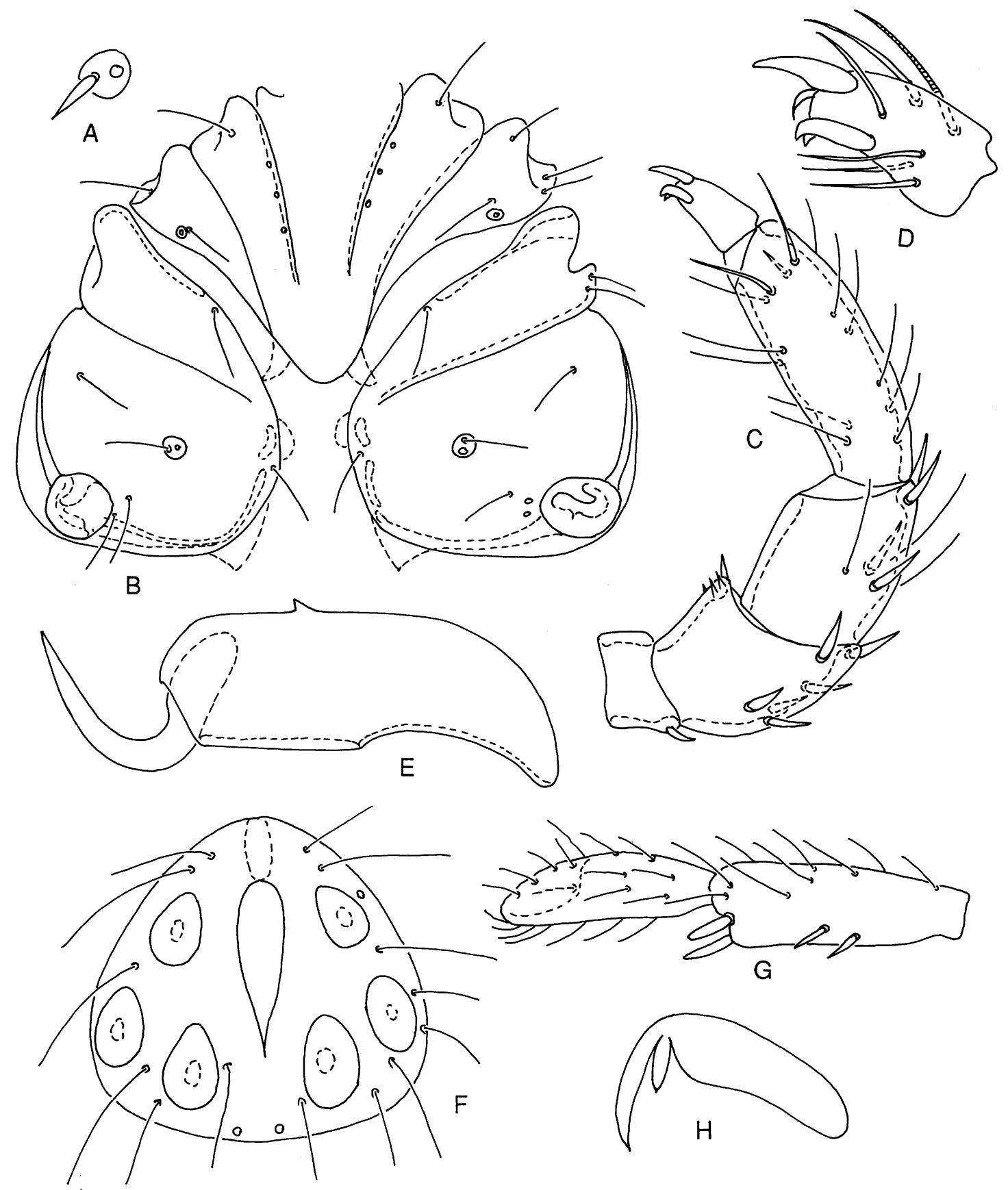

Fig. 9. Mixobates acutidentatus, male from the locus typicus. A seta Fch ; B coxal field ; C palpus, lateral view ; D P-5 ; E chelicera ; F genital field ; G I-L-5/6 ; H claw. 
its insertion sclerite ; Cx-1+2 (Fig. 10 B) weakly narrowed posteriorly and with broad, convex mediocaudal margin ; suture line $\mathrm{Cx}-3 / 4$ not reaching the medial margin of the plate, glandularia Pe approached to the suture line Cx-3/4 ; legs segments L (1-6) : I-L 48-55, 80-90, 90-100, 135-155, 140-155, 120-130 ; II-L 48-55, 75-90, 90-100, 140-165, 150-165, 130-145 ; III-L 55-65, 80-95, 95-110, 155-170, 170-180, 155-170 ; IV-L 105-120, 105-120, 135-145, 185-190, 205-220, 180-190 $\mu \mathrm{m}$; I-L-5 (Fig. $10 \mathrm{~F}$ ) with ventrodistal setae S- $1 / 2$ equal in size ; claws (Fig. $10 \mathrm{G}$ ) bearing a weakly developed claw blade with concave ventral margin and internal clawlet about $1 / 2 \mathrm{~L}$ of external claw. Genital field (Fig. $10 \mathrm{H}$ ) enlarged, triangular, L 105-115, W 120-165 $\mu \mathrm{m}$, acetabula large, Ac-3 major than Ac-1/Ac-2 ; gonopore L about 2/3 genital field L, 11-15 hairs on each side. Chelicera basal segment L 145-155, claw L $65 \mu \mathrm{m}$, basal segment nearly identical in height from the base to the tip, base of claw massive. Palpus (Fig. $10 \mathrm{C}, \mathrm{D})$ short and robust ; segments P-1-5 L 25-30, 80-90, 73-80, 90-100, 25-30 $\mu \mathrm{m}$; $\mathrm{P}-2$ ventrodistally without projection, bearing $8-12$ fine dents ; P-3 with straight and smooth ventral margin, $\mathrm{P}-4$ with a rounded projection near the insertion of the paired ventral hairs, P-5 (Fig. $10 \mathrm{D})$ rather short $(\mathrm{L} / \mathrm{H}$ 1.5), dorsodistal claw strong, the two ventrodistal claws strongly different in shape and dimensions : one of them truncated, the other one pointed and bent dorsally.

Female : Idiosoma L 490-695 $\mu \mathrm{m}$; coxal field (Fig. $11 \mathrm{~B})$ and legs as in males ; leg segments L : I-L 50-55, 95-105, 95-105, 140-155, 145-165, 125-140 ; II-L 50-55, 95-105, 100-105, 155-165, 165-170, 140-145, III-L 55-65, 95-105, 100-115, 165-180, 180-195, 165-170 ; IV-L 120-130, 115-125, 145-165, 205-210, 220-245, 185-195 $\mu \mathrm{m}$; genital plate L-shaped, narrow and elongated, as long as gonopore (Figs $11 \mathrm{C}, \mathrm{D})$, with $10-15$ genital hairs ; chelicera basal segment L 165 , claw 75-80 $\mu \mathrm{m}$; palp (Fig. $11 \mathrm{~A}$ ) L of segments 1-5 32-40, 90-100, 80-100, 100-105, $30 \mu \mathrm{m}$, larger than in male, with the ventral thickening on P-4 distinctly expressed.

Deutonymph : Idiosoma L $385 \mu \mathrm{m}$; Seta Fch (Fig. 12 A) about two times longer than diameter of insertion sclerites; coxae (Fig. 12 B) similar in shape to adults, but caudal apodemes of $\mathrm{Cx}-4$ longer and narrowed ; leg segments 1-6 L : I-L 25, 50, 50, 75, 75, 80 ; II-L 25, 50, 50, 75, 85, 85 ; III-L 30, 50, 50, 80, 90, 90 ; IV-L 50, 55, 70, 100, 115, $110 \mu \mathrm{m}$; I-L-5 with setae $\mathrm{S}-1 / 2$ rather large and identical in size (Fig. $12 \mathrm{D}$ ), external clawlet two times as long as internal one (Fig. $12 \mathrm{E})$; provisory genital field (Fig. $12 \mathrm{C}$ ) with straight anterior, and deeply indented posterior margins, bearing 3 paired hairs ; palp segments 1-5 L 16, 50, 50, 70, $20 \mu \mathrm{m}$, shape, number and arrangement of setae as given in Fig. 12 F ; P-2 with a single dent at its ventrodistal edge, P-3 ventrally smooth and straight. P-4 straight, without hump near the insertion of ventral hairs, P-5 with heteromorphic ventrodistal setae as described for adults.

Due to the shape of the posterior part of $\mathrm{Cx}-1 / 2$ (little narrowed, with largely rounded medioposterior margin) $M$. brachypalpis resembles $M$. processifer and $M$. incurvatus. From the latter species, it differs in the absence of a ventrodistal projection on P-2. M. brachypalpis can be easily distinguished from all so far known species of the genus due to the presence of a ventral hump in the centre of P-4, and the particular shape of the ventrodistal claws on P-5.

\section{Mixobates uncatellus Tuzovskij sp.n.}

Material : Holotype male, prep. 4956, Russia, Primorye Territory, Ussuri reserve, river Komarovka 17.07.1983, Vshivkova leg. ; paratypes : the same locality, 17./18.07.1983, 3 ơం', 3 우.

Male : Idiosoma L 570-655 $\mu \mathrm{m}$; setae Fch (Fig. 13 D) a little longer than the diameter of their insertion sclerites ; coxae (Fig. $13 \mathrm{C}$ ) with posterior part of CX$1+2$ narrowed, with equally rounded posteriomedial margin ; suture line Cx-3/4 in the medial third obsolete, not reaching the medial margin of the plate, glandularia Pe not in the centre of $\mathrm{Cx}-4$, but slightly approached to the suture $\mathrm{CX}-3 / 4$. Leg segments $1-6 \mathrm{~L}$ : I-L 4050, 75-80, 75-80, 120-130, 130-140, 115-120 ; II-L 4550, 75-80, 80-90, 130-140, 145-155, 130-140 ; III-L 55-60, 75-80, 95-100, 145-155, 165-170, 155-165, IVL 95-105, 95-105, 120-125, 170-180, 185-195, 165$180 \mu \mathrm{m}$; I-L-5 with setae S-1/2 equal in size, with rounded tips (Fig. $13 \mathrm{~F}$ ) ; claws (Fig. $13 \mathrm{G}$ ) with well developed claw blade, internal clawlet about $50 \% \mathrm{~L}$ of external clawlet. Genital field (Fig. 13 E) L 145-165, W 155-165 $\mu \mathrm{m}$; acetabula rather small, arranged in an obtuse triangle, gonopore long, with maximum width on the level of Ac-1, 11 genital hairs on each side. Chelicera basal segment L 105-115, claw L 40-50 um ; basal segment distally thickened, claw short, robust and crescent-shaped. Palp (Fig. 13 A) segments 1-5 L 2530, 75-80, 65-75, 95-105, 30-35 um ; P-2 with concave ventral margin, ventrodistally without projection, bearing 5-8 pointed denticles ; $\mathrm{P}-3$ with straight ventral margin, bearing 2-3 denticles in its distal part ; P-4 ventral margin slightly convex in the centre; P-5 (Fig. $13 \mathrm{~B}) \mathrm{L} / \mathrm{H}>2.0$, ventrodistal claws equal in shape and dimensions. 


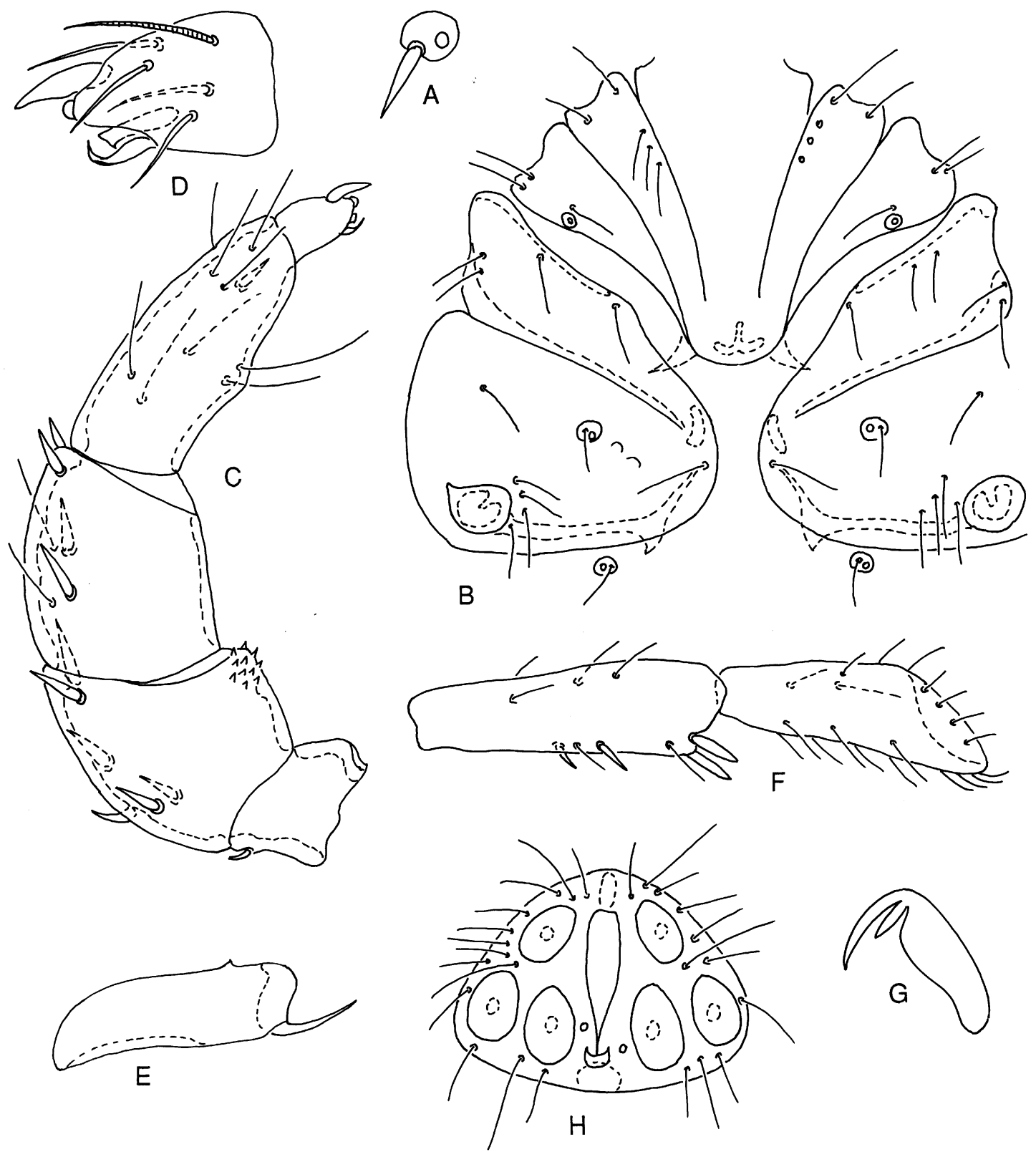

Fig. 10. Mixobates brachypalpis, male from the locus typicus. A seta Fch ; B coxal field ; C palpus, lateral view ; D P-5 ; E chelicera ; F I-L-5/6 ; G claw ; $\mathrm{H}$ genital field. 


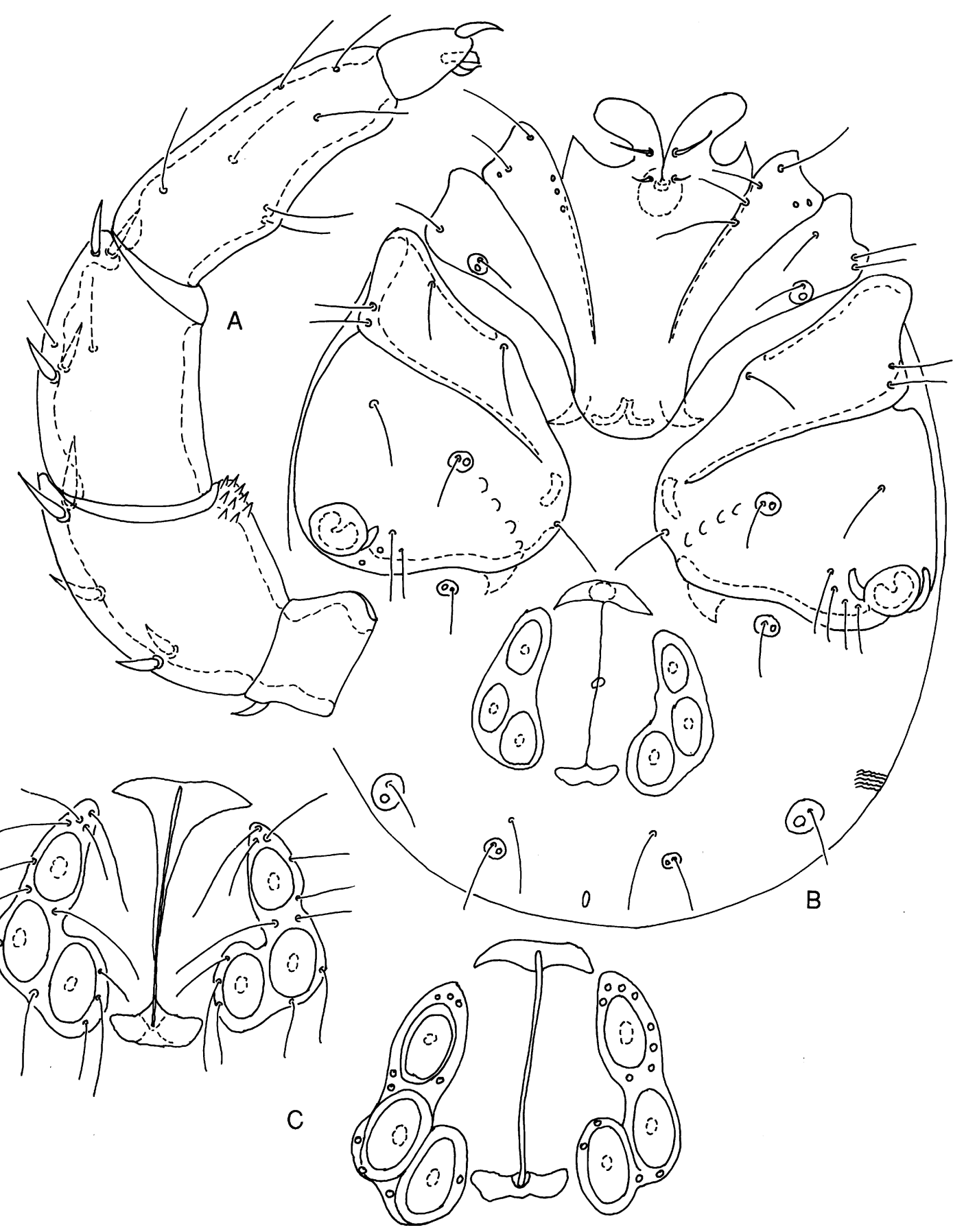

Fig. 11. Mixobates brachypalpis, female from the locus typicus. A palpus, lateral view ; B ventral idiosoma ; $\mathrm{C}$ genital fields of two specimens. 


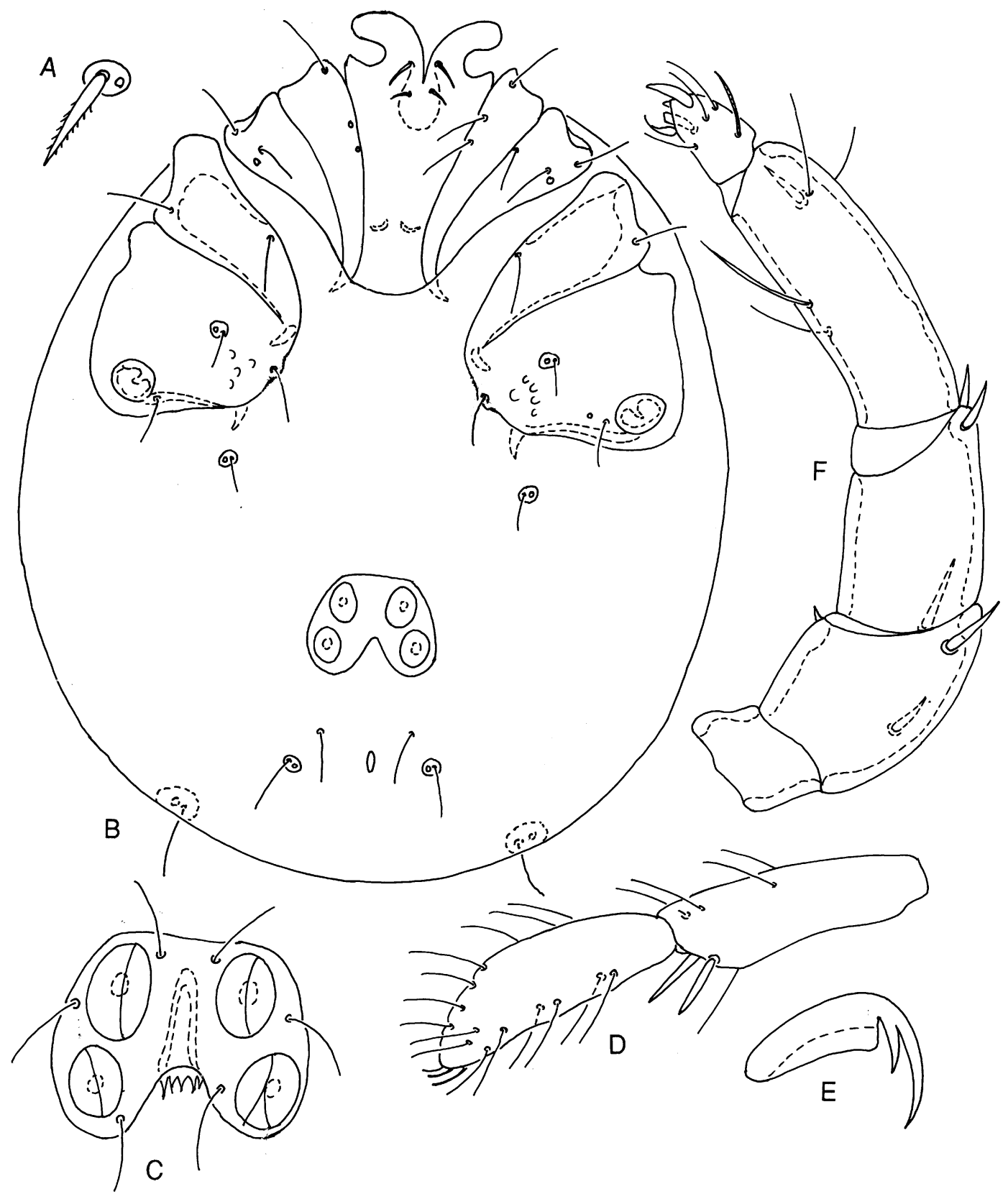

Fig. 12. Mixobates brachypalpis, deutonymph from the locus typicus. A seta Fch ; B ventral idiosoma ; C genital platelet ; D I-L-5/6 ; E claw ; F palpus, lateral view. 


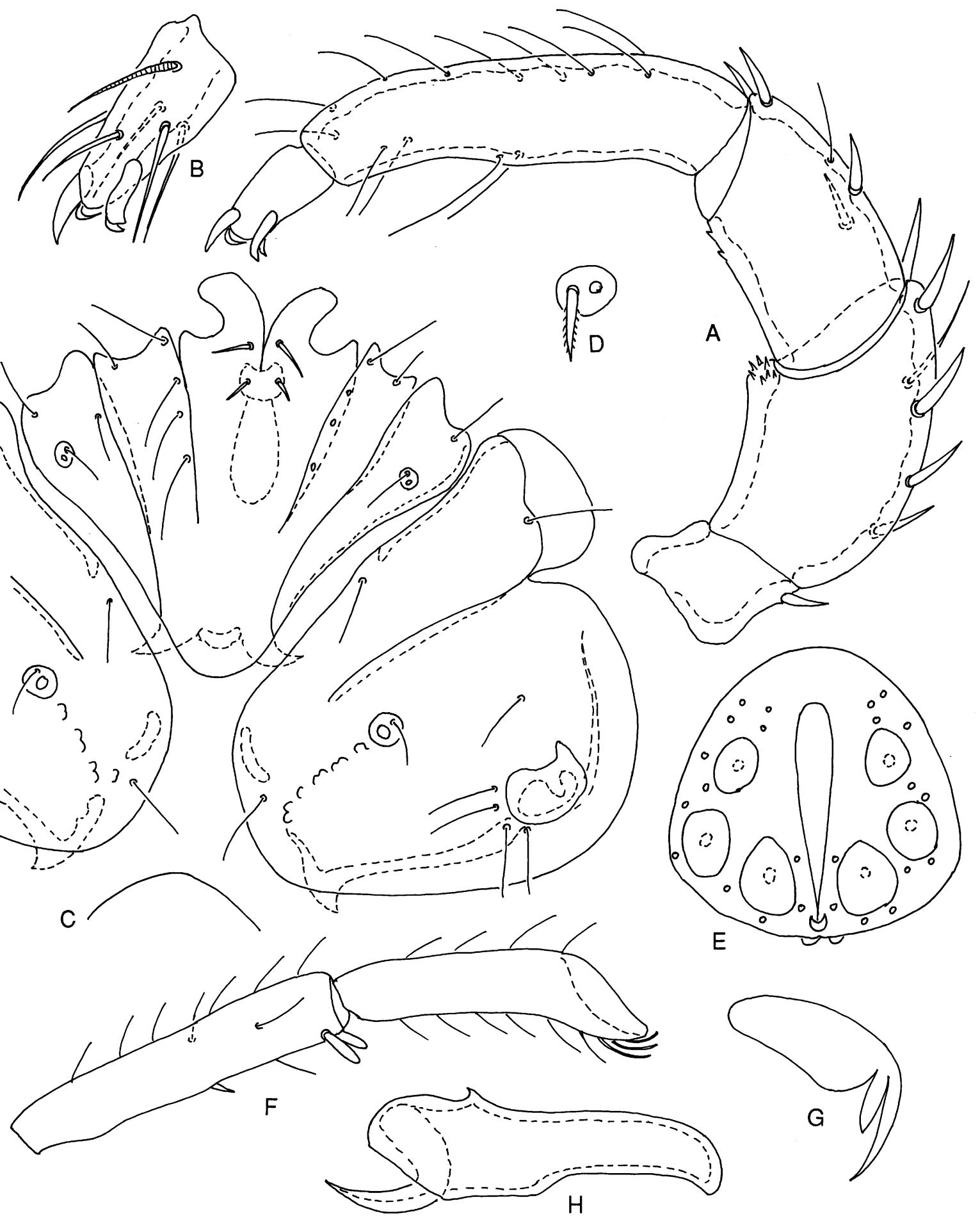

Fig. 13. Mixobates uncatellus, male from the locus typicus. A palpus medial view ; B P-5 ; C coxal field ; D seta Fch ; E genital field ; F I-L-5/6 ; G claw ; H chelicera. 
Female : Idiosoma L 530-735 um, coxae (Fig. 14 A) and legs as described for the male ; legs segments 1-6 L : I-L 40-50, 80-85, 80-85, 130-140, 135-140, 120-125, II-L 45-50, 75-80, 80-100, 140-145, 145-155, 125-130, III-L 55-65, 80-90, 105-110, 160-165, 170-180, 135-140, IV-L 105-140, 95-100, 135-140, 185-190, 190-195, 175-180 um ; Genital field : Figs 14 B, C, genital plate L 105-115, W 65-75 $\mu \mathrm{m}, \mathrm{L}$-shaped with deep medial indentation, in general Ac-3 larger than Ac- $1 / 2$, but occasionally Ac- $2 / 3$ equal in size (Fig. $14 \mathrm{C}$ ) ; gonopore distinctly longer than genital plate, praegenital sclerite very large ; Palp (Fig. $14 \mathrm{D})$ as in male, segments 1-5 L : 25-30, 80-90, 70$75,110-115,30-35 \mu \mathrm{m}$; P-2 ventrodistally with 5-8, P3 with 1-3 pointed denticles.

A denticulated P-3 is found also in $M$. caucasicus, a species differing from $M$. uncatellus in larger acetabula, longer setae $S-1 / 2$ on I-L-5, and leg claws with weakly developed claw blade and minor internal clawlets. M. uncatellus is similar to M. processifer in the shape of the posterior margin of $\mathrm{Cx}-1+2$, the absence of a ventrodistal projection on P-2, and the shape of leg claws. It can be distinguished from that species by the smaller acetabula and the presence of denticles on the ventral surface of P-3 in both sexes. Acetabula of similarly small dimensions are present also in M. acutidentatus. This species which is not known in the female sex differs from $M$. uncatellus in major setae $\mathrm{S}-1 / 2$, and in a shorter male gonopore.

\section{Mixobates maghrebinus Gerecke sp.n.}

Material examined : Holotype male, Morocco MAR 43, Rif, Brickcha, affluent river Loukos, 2 km S Maison Forestière Bellota, 10.04.1998 Gerecke ; paratypes : same collecting site and date $50^{\top} 0^{\prime \prime}, 1$ ㅇ.

Male : Idiosoma L 425, W $390 \mu \mathrm{m}$, Setae Fch (as in Fig. $16 \mathrm{~B}$ for the female) short and thick, as long as the diameter of their insertion platelet; ventral view : Fig. $15 \mathrm{~A}$, all coxae fused by secondary sclerotization to a unique coxal plate to which also the anterior margin of the genital plate is merged. However, all plate border lines are still visible, and a broad, equally rounded medioposterior margin of $\mathrm{Cx}-1+2$ is recognizeable ; suture line $\mathrm{Cx}-3 / 4$ little distinct, but visible on the whole length up to the medial margin of the plate ; glandulare Pe approached to the suture line $\mathrm{Cx}-3 / 4$, setae Le included into the secondary sclerotization border ; I-L$5 / 6$ short and stout, L 108/100 $\mu \mathrm{m}$, setae S-1/2 relatively long (L $23 \mu \mathrm{m})$, with rounded tips, claw with a very narrow claw blade and short internal clawlet (L about $1 / 4 \mathrm{~L}$ external clawlet) ; genital field triangular, L/W 121/123 $\mu \mathrm{m}$, with a little mediocaudal projection, acetabula minute in dimensions, in triangular position, separated from each other by extended areas of plate surface, gonopore L about $50 \%$ plate L, maximum width in the centre ; 14-15 hairs on each side. Chelicera (see Fig. $16 \mathrm{C}$ for the female) basal segment L 112, claw L $56 \mu \mathrm{m}$, basal segment distally thickened, claw relatively short, equally curved ; Palpus as given in Fig. 16 D, E for the female, segment 1-5 L 25, 74, 54, $100,43 \mu \mathrm{m} ; \mathrm{P}-2$ slender (L/H 1.7), with straight ventral margin and lacking a ventrodistal projection ; P-2 and $\mathrm{P}-3$ without ventral denticulation ; $\mathrm{P}-4$ robust, with straight ventral margin ; P-5 slender (L/H about 2.0), with dorsodistal claw little prominent and ventrodistal claws equal in size and dimensions.

Female : Idiosoma L 470, W $380 \mu \mathrm{m}$; as in male, all coxae fused by secondary sclerotization to a unique coxal plate to which also the anterior margin of the praegenital sclerite is merged (Fig. $16 \mathrm{~A}$ ) ; I-L-5/6 as given in Fig. 15 B for males, L 143/134, S-1 L $28 \mu \mathrm{m}$; praegenital sclerite very large (W $100 \mu \mathrm{m})$, genital plates L/W 78/47 $\mu \mathrm{m}$, with equally concave medial margin and rounded anterior and posterior edges, acetabula arranged in a curved line, 11-12 genital hairs on each side ; chelicera basal segment (Fig. 16 C) almost three times longer than claw. Palpus (Fig. 16 D) as described for the male, segment 1-5 L 24, 76, 56, 99, $43 \mu \mathrm{m}$.

Both sexes of M. maghrebinus differ from all known palaearctic species in the extended secondary sclerotization, merging all coxae to a unique coxal shield, and the P-2 completely lacking ventral denticulation. Such a character combination is found only in a nearctic species, M. inermis (Cook, 1974) from Montana and Wyoming. M. inermis differs from $M$. maghrebinus in the obliterated medial suture lines of $\mathrm{Cx}-3 / 4$ on the coxal plate, larger acetabula, and the medial margins of the female coxal plates deeply indented, not concave, on the level of Ac-2.

\section{A key to the palaearctic species of the genus Mixobates}

1 (2) All coxae merged by secondary sclerotisation to a unique coxal shield, that includes also the setae Le and the anterior margin of the genital field. Palpus without ventral denticulation.

\section{M. maghrebinus}

2 (1) Coxae arranged in three plates $(\mathrm{Cx}-1+2$, right and left $\mathrm{Cx}-3+4)$, at maximum a lateral fusion between Cx-2 and Cx-3 may exist, but secondary sclerotization does not extend between the medial margins of $\mathrm{Cx}-3 / 4$ 


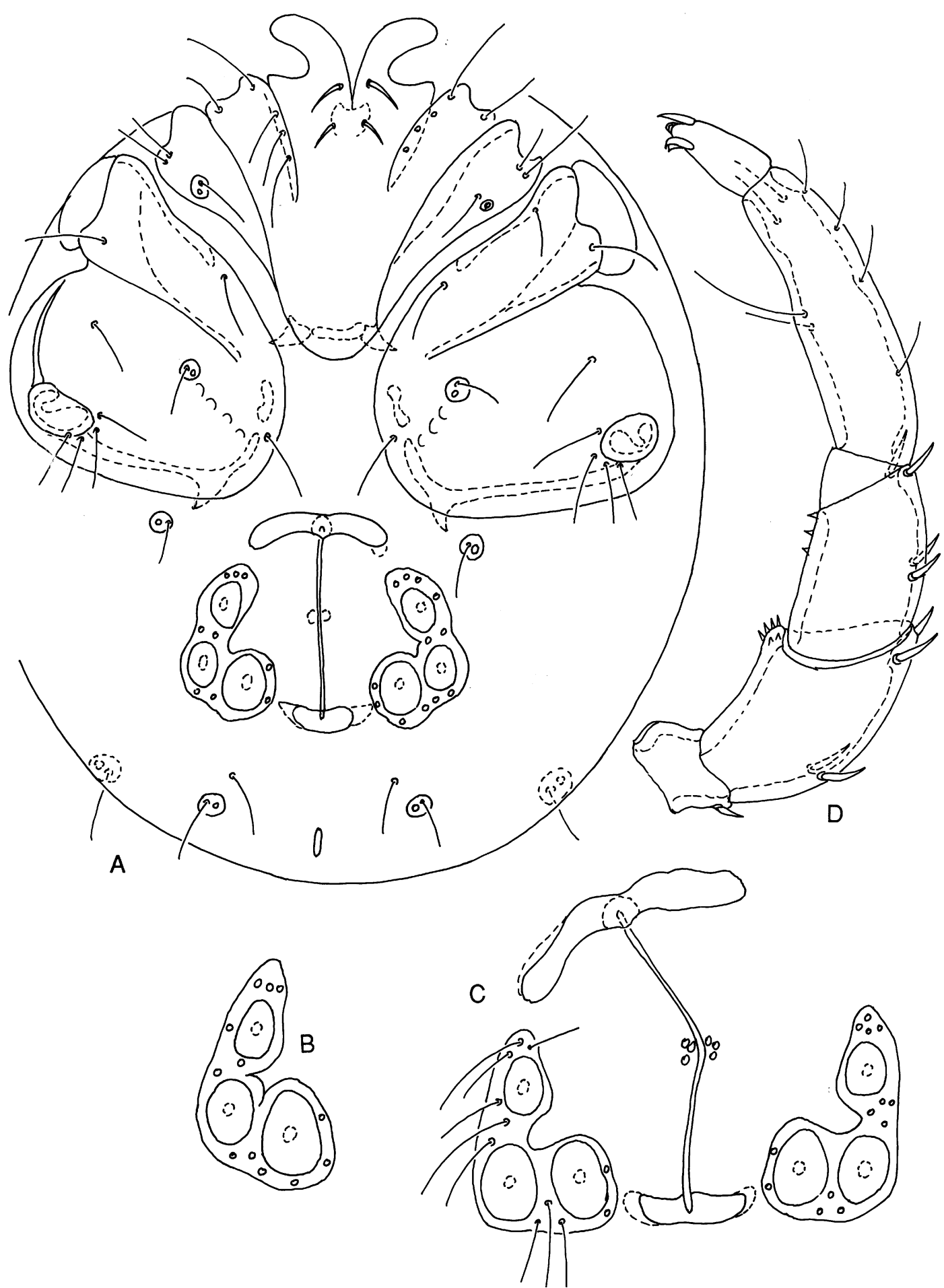

Fig. 14. Mixobates uncatellus, female from the locus typicus. A ventral idiosoma; B genital plate ; C genital field ; D palpus, lateral view. 


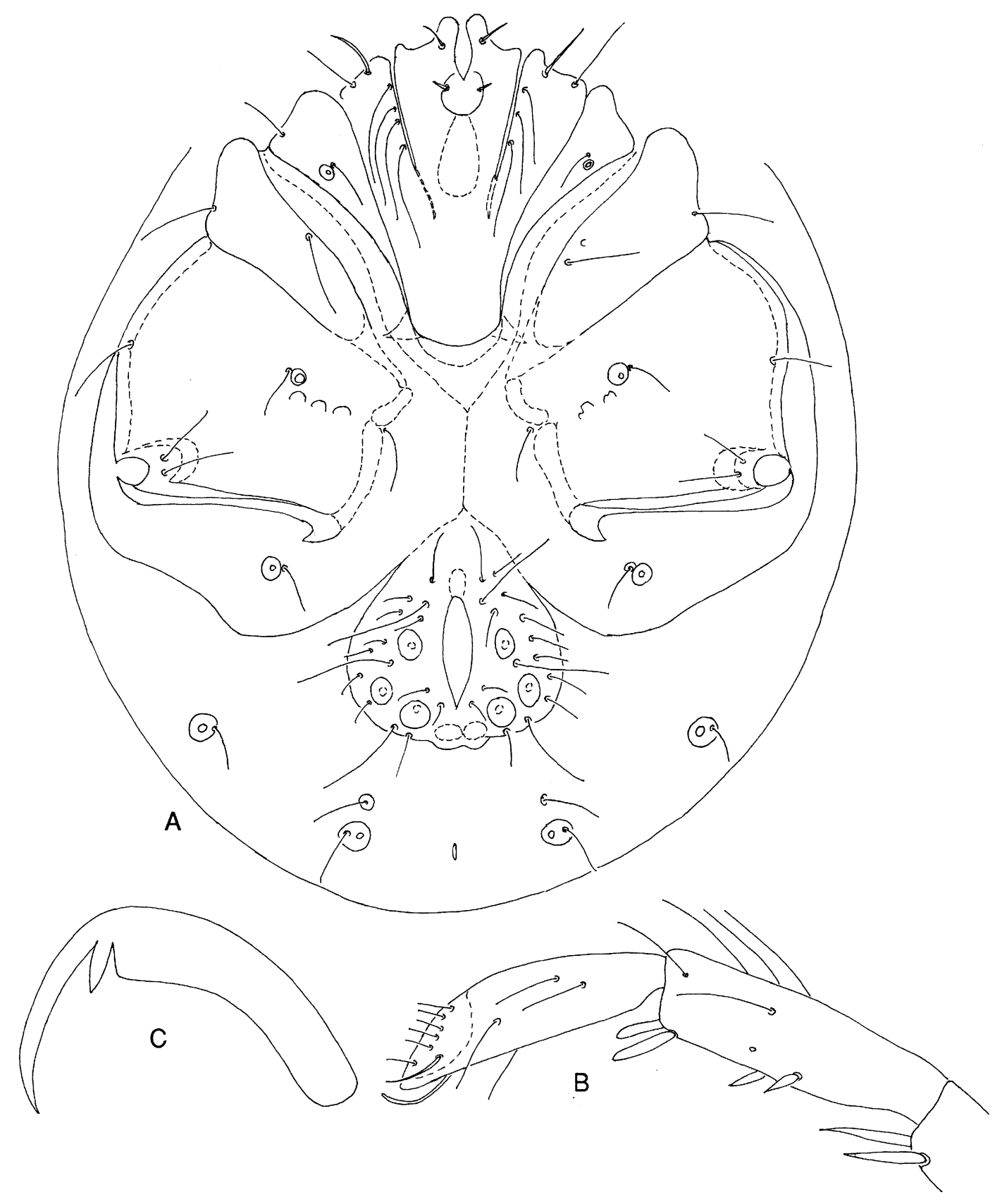

Fig. 15. Mixobates maghrebinus, male from the locus typicus. A ventral idiosoma ; B I-L-5/6 ; C claw. 


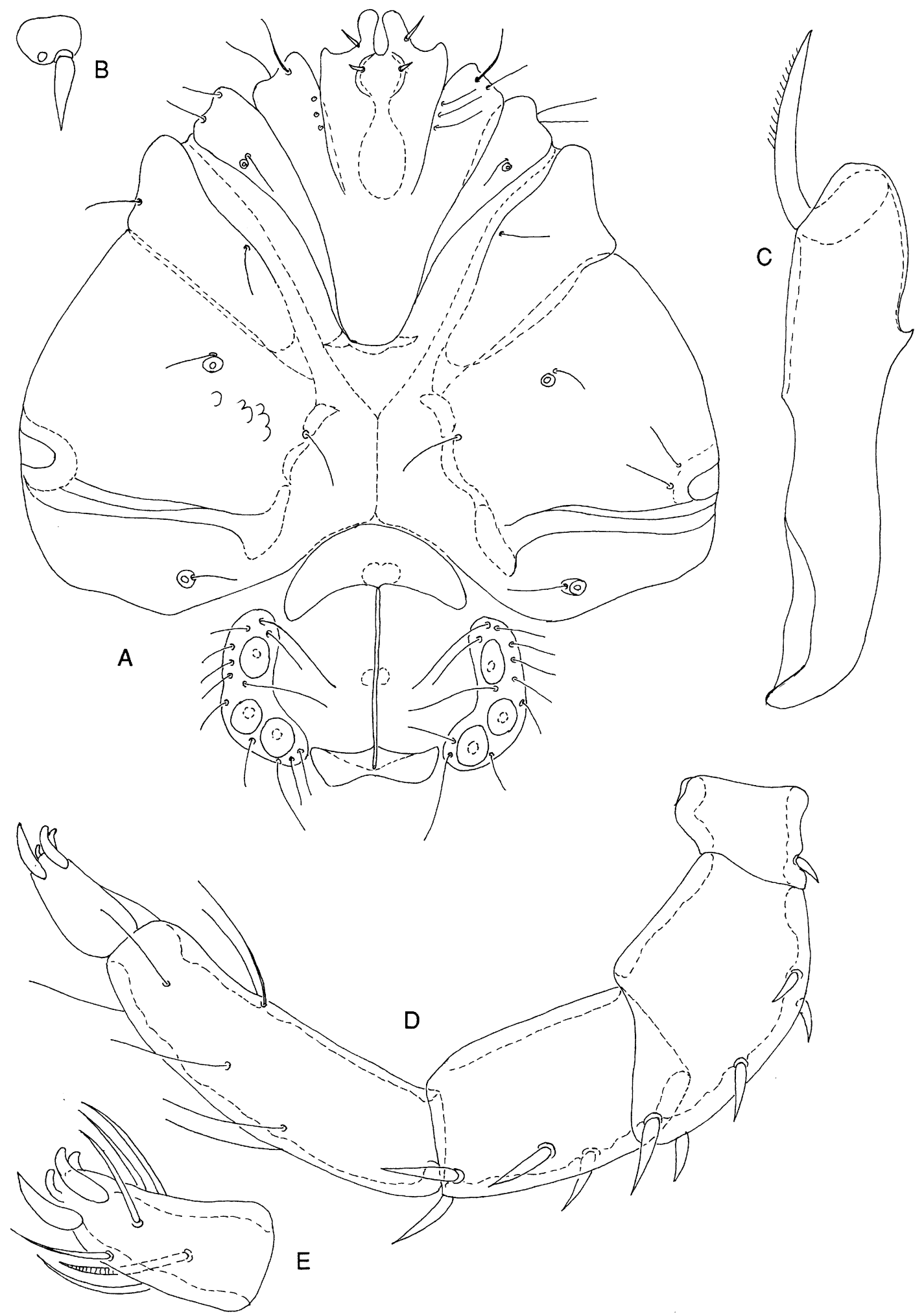

Fig. 16. Mixobates maghrebinus, female from the locus typicus. A coxal and genital field ; B seta Fch ; C chelicera ; D palpus laterally ; E P-5. 
and never includes setae Le. At least P-2 with ventrodistal denticulation.

$$
3
$$

3 (4) P-2 with a well developed, pointed ventrodistal projection

\section{M. incurvatus}

4 (3) P-2 without a distinct, pointed, ventrodistal projection

$$
5
$$

5 (6) P-5 with modified (truncated, upwards bent) ventrodistal claws, P-4 with a hump near the insertion of the ventral setae

\section{M. brachypalpis}

6 (5) P-5 with normal (pointed, downwards bent) ventrodistal claws, ventral margin of P-4 without a hump near the insertion of the ventral setae

7 (8) P-3 without ventral denticulation.

9

8 (7) P-3 with ventral denticulation

11

9 (10) ventrodistal setae on I-L-5 shorter (17-20 $\mu \mathrm{m})$, acetabula larger (maximum diameter 35-45 $\mu \mathrm{m}$ ), leg claw blade and internal clawlet small

\section{M. processifer}

10 (9) (only male sex known!) ventrodistal setae on I-L-5 longer (22-24 $\mu \mathrm{m})$, acetabula minor (maximum diameter 23-30 $\mu \mathrm{m}$ ), leg claw blade and internal clawlet large

\section{M. acutidentatus}

11 (12) acetabula large, in males covering extended parts of the genital plate, ventrodistal setae I-L-5 long, leg claws with weakly developed claw blade and minor internal clawlets.

\section{M. caucasicus}

12 (11) acetabula minor, in males separated by larger bridges of genital plate surface, ventrodistal setae I-L-5 shorter, leg claws with large claw blade and major internal clawlets.

\section{M. uncatellus}

\section{Acknowledgements}

The initial work for this revision found financial assistance by a travel grant of the DFG to the senior author, by generous sponsoring from Leica Microsystems, and by logistic support from the Zoological Institute Tübingen. Tatjana Vshivkowa and Jürgen Schwoerbel made available specimens from their collections, J. Kolibac (Brno, Czechia) and T. Kronestedt (Stockholm, Sweden) helped us with sending of type material. Two anonymous referees improved language and contents of this paper. We say our sincere thanks to all these persons and institutions.

\section{References}

Angelier E., Decamps H. \& Rey J. - 1963. Les Hydracariens de Céret : Étude systématique et écologique. Bull. Soc. Hist. nat. Toulouse, 98 (3-4), 459-500.

Böttger K. \& Ullrich F. 1974. - Hydrachnellae (Acari) aus Schwedisch-Lappland. Ent. Tidskrift, 95 (1), 73-76.

Cook D.R. 1974. - Water mite genera and subgenera. Mem. Amer. Entomol. Inst., 21, 1-860.

Gerecke R. 2000. - New data on the morphology and distribution of Mesobates forcipatus Thor, 1901, and observations on the systematics of Atractides-like water mites (Acari, Actinedida, Hygrobatidae). Aquatic Insects, 22 (3), 209-217.

Gerecke R. in press. - Water mites of the genus Atractides Koch, 1837 (Acari : Parasitengona : Hygrobatidae) in the Western palaearctic region : a revision. Zool. J. Linn. Soc. London, 136.

Gerecke R. \& Tuzovskij P. 2001. - The water mite Rutripalpus limicola Sokolow, 1934 : new data on morphology and biology, and considerations on the systematic position of the monotypic family Rutripalpidae (Acari, Hydrachnidia). J. Nat. Hist., 35, 931-944.

Habeeb H. 1955. - North American Hydrachnellae 32-34. Leafl. Acadian Biol., 7, 1-7.

Habeeb H. 1957. - New Hydrachnellae from North Carolina. Leafl. Acadian Biol., 15, 1-8.

Habeeb H. 1962. - New water mites from Arizona and New Mexico. Leafl. Acadian Biol., 28, 1-4.

Láska F. 1954. — Zwei neue Hygrobates-Arten (Hydrachnellae, Acari) aus der Slowakei. Zool. Anz,. 152 (1-2), 36-38.

Láska 1959a. - Vodule (Hydrachnellae) z provodí horní Nitry. Príodoved Sborn. Slovensk. Muzea, 5, 5-38.

Láska F. 1966. - Vodule slezské oblasti (Hydrachnellae, Acari). Acta Mus. Silesiae (A), 15, 55-141.

Lundblad O. 1927. - Einige Bemerkungen zur Systematik der Familie Hygrobatidae. Zool. Anz., 72 (1-2), 55-65.

Lundblad O. 1962. — Die Hydracarinen Schwedens. II. Ark. Zool., (2) 14 (1), 1-635.

Schwoerbel J. 1957. - Wassermilben aus dem Gebiet der oberen Donau (Acari, Hydrachnellae). Mitt. Bad. Landesver. Naturkde. Naturschutz (N.F.), 7 (1), 25-39.

Sokolow I.I. 1930. - Beiträge zur Kenntnis der Hydracarinen Sibiriens. Arch. Hydrobiol., 22, 306-350.

Sokolow I.I. 1934. - Beiträge zur Kenntnis der Hydracarinenfauna des Ussuri-Gebiets. II. Hydracarinen der Fliessenden Gewässer. Zool. Jb. Syst., 65 3-4, 309 -388.

Sokolow I.I. 1940. - Hydracarina (Ire partie : Hydrachnellae). In : Sernow, S.A. \& Stackelberg, A.A. (eds) : Faune de l'URSS. Arachnides, 5, 2, $24+511$ pp. (in Russ.).

Thor S. 1905. - Eine neue Hygrobates-Art, Mixobates nov. subgenus. Zool. Anz., 29 (11), 371-373.

Tuzovskij P.V. 1987. - Morphology and postembryonal development of water mites. Moscow (Nauka), 1-172 (in Russ.).

Tuzovskij P.V. 1990. - Key to deutonymphs of water mites. Moscow (Nauka), 1-238 (in Russ.).

Viets K. 1956. - Die Milben des Süßwassers und des Meeres. Hydrachnellae et Halacaridae (Acari). II. und III. Teil : Katalog und Nomenklator. Jena (G. Fischer), $870 \mathrm{p}$.

Viets K. \& Viets K.O. 1960. - Nachtrag zu : Dr. Karl Viets, Bremen, Abteilung : Wassermilben, Hydracarina. pages 1-44 in : Brohmer P. ; Ehrmann P. \& Ulmer G. (eds) : Die Tierwelt Mitteleuropas, 3 (4), Ergänzung, Leipzig (Quelle \& Meyer).

Viets K.O. 1978. - Neue und seltene Wassermilben (Hydrachnellae, Acari) aus Guatemala. Teil IV. Acarologia 19 (3), 463-483.

Viets K.O. 1987. — Die Milben des Süßwassers (Hydrachnellae und Halacaridae [part.], Acari). II. : Katalog. Sonderbände des Naturwiss. Vereins Hamburg, 8, 1-1012. 